\title{
Heavy metals in sands of sandboxes: health risk associated with their quantities and form of occurrence in some spas of Poland
}

\author{
Alicja Kicińska $^{1}$ - Magdalena Mamak ${ }^{1}$ - Monika Skrzypek ${ }^{1}$
}

Received: 6 February 2017 / Accepted: 12 June 2017 /Published online: 6 July 2017

(C) The Author(s) 2017. This article is an open access publication

\begin{abstract}
The authors dealt with some hazardous elements, i.e. $\mathrm{As}, \mathrm{Cd}, \mathrm{Co}, \mathrm{Cr}, \mathrm{Cu}, \mathrm{Ni}, \mathrm{Pb}$ and $\mathrm{Zn}$, contained in sands of the sandboxes localized in playgrounds of seven spas in southern Poland (CEE). The following determinations were made: the total contents of metals, the most mobile metals (waterleachable fraction) and the metals available to plants and organisms $\left(\mathrm{CaCl}_{2}\right.$ - and EDTA-extractable fractions). The totals of the metals are below the upper limits of the values recommended for soils of the protected areas (type A). The mobility of the metals is low: the forms leachable with water range from $0.7 \%$ of the total content (TC) of $\mathrm{Pb}$ to $13.4 \% \mathrm{TC}$ of $\mathrm{Cd}$. The forms available to living organisms contain considerably higher quantities of the metals: from $2.3 \% \mathrm{TC}$ of $\mathrm{Ni}$ to $22.6 \% \mathrm{TC}$ of As in $\mathrm{CaCl}_{2}$-extractable fractions and from $0.7 \%$ TC of Cr to $82 \%$ TC of As in EDTA-extractable fractions. An assessment of the health risk indicates that children are exposed to the metals present in the sandboxes mostly due to inadvertent swallowing of "dirt" from their hands. The highest are the $\mathrm{HQ}_{\text {ingestion }}$ indexes of $\mathrm{As}$ and $\mathrm{Cr}$, both for the 3-yearold permanent spa residents $(5.74 \mathrm{E}-02$ and $1.71 \mathrm{E}-02$, respectively) and the spa visitors of the same age (7.47E-03 and $2.22 \mathrm{E}-03$, respectively) and the 6-year-old residents $(4.31 \mathrm{E}$ -02 and $1.28 \mathrm{E}-02$, respectively) and visitors $(5.60 \mathrm{E}-03$ and $1.66 \mathrm{E}-03$, respectively). The health risk indexes $H I$ in the case of non-cancerogenic substances for children 3 and 6 years old are for spa residents, $9.59 \mathrm{E}-02$ and $7.19 \mathrm{E}-02$,
\end{abstract}

Responsible editor: Philippe Garrigues

Alicja Kicińska

kicinska@geol.agh.edu.pl

1 Faculty of Geology, Geophysics and Environmental Protection, AGH University of Science and Technology, Al. Mickiewicza 30, 30-059 Krakow, Poland respectively, and for children visitors, who are exposed to environmental factors for a much shorter time than the residents, $1.25 \mathrm{E}-02$ and $9.35 \mathrm{E}-03$, respectively. All the risk indexes have their values significantly below 1 , which proves the lack of deleterious effects resulting from the exposition of children to the elements considered. The children of both age groups, exposed to the cancerogenic substances, are endangered mainly by As. The risk values of the cancerogenic As for 3- and 6-year-old children residents are 1.27E-06 and $1.90 \mathrm{E}-06$, respectively, and for children visitors of the same ages $1.65 \mathrm{E}-07$ and $2.47 \mathrm{E}-07$, respectively. These values are significantly lower than a permissible level of "1.10E- 05 " and means that also in this case, the health risk is minimal. The risk values calculated for the remaining metals are much lower and follow the sequence $\mathrm{Cr}>\mathrm{Co}>\mathrm{Cd}$. However, an adverse impact of some sand-contained pollutants that are attributed to the motor traffic $(\mathrm{Cu}, \mathrm{Zn}, \mathrm{Ni}, \mathrm{Cr}, \mathrm{Co}$ and $\mathrm{Pb})$ and low emissions (mainly As and $\mathrm{Cd}$ ) has been established in the spa resorts in question.

Keywords Heavy metals - Sandboxes $\cdot$ Risk assessment . Health resorts · CEE

\section{Introduction}

Spas are defined as the localities in which the medical treatment based on natural resources, i.e. mineral and therapeutic waters, peloids and therapeutic gases, is offered. Each spa has its specific medicinal profile and offers bathing, crenotherapy, inhalations, irrigations and rinsing, depending on the infrastructure available (hospitals, sanatoriums, ambulatories or physiotherapeutic facilities).

It is rather difficult to establish the number of spas in the world because of various definitions of the very concept of the 
"spa" term. An estimation gives a number of over 590 localities fulfilling all the criteria ascribed to the spas proper (health resorts); however, spa-like localities and the localities with substantial resources of thermal waters also pretend to be included into this group (Dryglas and Różycki 2016). The number of such spa-pretending centres in Europe itself is above 200, mainly in Hungary and Slovakia. The leaders of the statutory spa localities in Europe are Germany (268), Austria (96), Poland (45), France (44) and the Czech Republic (40). Outside Europe, the country with the highest number of statutory spas is Japan (76) that is also regarded as the birthplace of therapeutic thermal bathing (Smith and Puczko 2009).

Apart of the therapeutic treatment that uses natural balneological resources, it is the long-lasting stay in spa resorts that matters but only if their climate brings about nonquestionable medical advantages. The duration of such periods is usually $2-3$ weeks, and a stay should be spent in a microclimate free of pollutants. Only then will result the spa staying in a detoxication of human organisms and a general health improvement.

Legislation systems of major European countries contain stipulations enforcing local administrations to pursue a proper environmental policy, based not only on the sustainable management of natural balneological resources, but also on a taking care of the whole infrastructure, including water and sewerage systems, energy sector, public transport and waste management. Considering such a policy that is aimed at providing and maintaining a proper microclimate within spas, the resort localities are usually divided into internal protection zones. For instance, in Poland, there are three zones distinguished (A, B and C), two with a specified contribution of green areas: zone $\mathrm{A}-75 \%$, zone $\mathrm{B}$ at least $55 \%$, while zone $\mathrm{C}$ plays a role of a buffer to zone B; this division should provide a comfort of stay and a proper recuperation of spa visitors (Minister 2005). The spa green areas include first of all not only parks, but also promenades, playgrounds and recreational facilities. These are just the places where the spa visitors spend most of their time in the open. The role of playgrounds is specific. Equipped in sandboxes, toys and other playing facilities, they attract children, who spend there at least several hours a day during their stay in the spa. Unfortunately, despite an overall public awareness and preventive measures, spas are also exposed to pollution, mainly associated with the motor traffic: for instance, a considerable majority of spa visitors use their private cars. Heating houses with coal (usually of inferior quality, sometimes with coal muds), fine coke and/or wood is another source of pollution in Polish spas, particularly those in the mountainous parts of the country. This problem, called the low emission, becomes serious mainly in the heating season (late autumn-early spring), when the number of visitors is also high and their living quarters must attain adequate temperatures (Siudek et al. 2016). In many spas, there is no regular environmental monitoring; therefore, the question "whether a longer stay in the spa is healthy for its visitors or not" is fully justified. It is particularly important in the case of youngsters, because their being exposed to the presence of hazardous elements or substances in elevated doses may cause negative health effects (Szyczewski et al. 2009; Siudek et al. 2015). Into this dangerous group definitely belong heavy metals, particularly $\mathrm{Cd}, \mathrm{Co}, \mathrm{Cr}, \mathrm{Pb}$ and As (the latter formally a metalloid), which not only disturb proper functioning of young organisms, but may also irreversibly affect their further, proper development (Kabata-Pendias et al. 1993).

The health of the humans exposed to heavy metals is endangered considering three access paths of pollutants: they enter an organism by breathing, swallowing (common at children who often put dirty hands into their mouths) and skin penetrating. In all three cases, potential toxic elements are contained mainly in the finest fractions of airborne dusts $\left(\mathrm{PM}_{10}, \mathrm{PM}_{2.5}\right)$, whose quantities of various organic and inorganic compounds are not always neutral to humans (Kicińska 2016a, b; Pysz et al. 2016; Zwozdziak et al. 2016).

Heavy metals regardless of their origin (natural or anthropogenic) represent a serious environmental threat, resulting mainly from their relatively easy bioaccumulation and biomagnification. Metabolism of some of them (e.g. $\mathrm{Cu}, \mathrm{Cd}$ and $\mathrm{Zn}$ ) is controlled by genetic factors and is associated with the capability of organisms to synthesize metaloenzymes and metaloproteins (for instance, metalothionine), which increase resistance to toxic effects of metals (Erway 1984; Ernst 1996). According to Szpunar et al. (2003), human organisms can complexate trace elements predominantly by proteins and their constituents (via the sulphur atom in the case of $\mathrm{Cu}, \mathrm{Zn}$ and $\mathrm{Cd}$ and the oxygen atom in the case of $\mathrm{Co}, \mathrm{Ni}, \mathrm{Cu}$ and $\mathrm{Zn}$ ), nucleic acids and their constituents $(\mathrm{Cr}, \mathrm{Ni})$, polysaccharides $(\mathrm{Pb})$, tetrapyrrole ligands (Co and $\mathrm{Ni}$ ) and small organic ligands $(\mathrm{Ni})$. Some of the metals mentioned are indispensable for a proper functioning of the organism. For instance, Co is contained in cobalamine (vitamin $\mathrm{B}_{12}$ ) and plays an essential role in the formation of red blood cells and the metabolism of nucleic acids and proteins. Chromium is contained in trypsin and is an important factor of metabolism of glucose, some proteins and fats. A deficiency of $\mathrm{Zn}$ disturbs the development of the bone system and the reproductive functions and affects skin causing its inflammation. On the other hand, a longlasting excess not only of $\mathrm{Zn}$, but also of $\mathrm{As}$ and $\mathrm{Ni}$, in the organism may be carcinogenic. Excessive quantities of $\mathrm{Cu}$ and $\mathrm{Pb}$ in children's organisms result in disorders of the brain and physical development and are a cause of liver diseases.

Investigations on the health risk of children arising from the presence of metals in the environment were carried out so far mainly in playgrounds and urban parks of larger agglomerations with industrial facilities (De Miguel et al. 2007; Figueiredo et al. 2011; Namik et al. 2012; Verla et al. 2015). The subjects of these studies included soils (Diatta and Grzebisz 2011; Figueiredo et al. 2011; Guney et al. 2010; 
Stajic et al. 2016; Verla et al. 2015), urban dusts (Boldo et al. 2006; Kicińska and Bożęcki 2017; Khaniabadi et al. 2016; Lim et al. 2011; Mazzei et al. 2008; Yu et al. 2013; Wang et al. 2016; Zhang et al. 2015) and road dusts (Du et al. 2013; Ferreira-Baptista and De Miguel 2005). Only subordinate are the papers devoted to pollution of health resorts and their playing grounds, not saying on sandboxes and the sand that fills them (Jasiewicz et al. 2009; De Miguel et al. 2007; Nieć et al. 2013), although these facilities are most willingly used by children playing outdoor.

Considering the problems described, in seven spas of southern Poland (CEE), the sand of playground sandboxes was sampled in 2016 and the analyses, followed by recalculations and evaluations of their results, included the following:

1. The total contents (TC) of selected heavy metals associated with the motor traffic $(\mathrm{Cu}, \mathrm{Zn}, \mathrm{Ni}, \mathrm{Cr}, \mathrm{Co}$ and $\mathrm{Pb})$ and the low emissions (mainly As and $\mathrm{Cd}$ )

2. The contents of easily soluble metals, i.e. those more mobile and bioavailable (e.g. for plants and soil organisms)

3. An identification of the source(s) of the metals

4. Calculations of the hazard quotient $\left(\mathrm{HQ}_{i}\right)$ of three access routes of the elements that enter the human organism ( $\left.\mathrm{HQ}_{\text {ingestion }}, \mathrm{HQ}_{\text {inhalation }}, \mathrm{HQ}_{\text {dermal }}\right)$ and the hazard index (HI) for threshold-acting (non-cancerogenic) substances and cancer risk for non-threshold-acting (cancerogenic) substances in the case of children frequenting the playgrounds and being exposed to the toxic elements. Two groups of children have been distinguished in the investigations: those being the permanent inhabitants of the spa (i.e. residents) and those coming there only for shorter stays (i.e. visitors).

\section{Sampling sites}

The spas in question are located in the Polish part of the Carpathian Mountains, in the Małopolska Voivodeship (Fig. 1), a region located within the moderate climate with transitional features. The spa status was granted all the seven localities in the same time (1967). Six of them, i.e. Krynica, Muszyna, Rabka, Piwniczna, Szczawnica and Wysowa, are situated in foothill and mountainous bioclimatic regions, where the climate conditions strongly vary and are highly stimulating. The seventh of them, Swoszowice, is located in the lowermost, northern margin part of the Carpathian Foothills, and represents a subregion of an elevated thermal stimulation. Mineral waters are the major medicinal natural assets of all the spas, and the spectrum of therapeutic treatments ranges from four to ten (Table 1). For instance, the disorders of the upper and lower respiratory tracts are treated in the six aforementioned spas, with Swoszowice being again an exception.
In each of the seven spas were identified from two to four playgrounds with sandboxes. The sand samples were collected in four corners of each sandbox, each of the samples weighing around $0.5 \mathrm{~kg}$; a total of 88 samples represented thus the initial study set. Next, the four samples from every sandbox were mixed together and homogenized; in this way, 22 general samples with the weight around $2 \mathrm{~kg}$ each were obtained. The field campaign covered the period of September and October 2016.

\section{Laboratory methods}

The study material was dried, homogenized once again and prepared for chemical analyses. They were carried out at the Laboratory of Trace Analyses at the Department of the Environment Protection, AGH University of Science and Technology. In the first stage, the grain fraction $>2 \mathrm{~mm}$ was removed and the remaining $<2-\mathrm{mm}$ analytical samples had their $\mathrm{pH}$ determined in water according to the standard PNISO 10390. The most mobile metals were assayed after their leaching with distilled water at the solid to water ratio 1:10.

The determinations of the bioavailable (e.g. for plants and soil organism) quantities of metals were conducted after a 2.5-h extraction of the analytical samples with $0.01 \mathrm{M}$ solution of $\mathrm{CaCl}_{2}$ at the solid-to=liquid ratio 1:10 (Rauret 1998; Pueyo et al. 2004) and with $0.02 \mathrm{M}$ solution of EDTA at the solid-toliquid ratio 1:10. EDTA is used extensively in soil sciences to determine the bioavailability of trace elements (including metals) and possible decontamination methods of polluted soils. Since the EDTA leaching is of a non-selective nature, the co-dissolution of major elements also takes place (Manouchehri et al. 2006; Lo and Yang 1999). In the case of the $\mathrm{CaCl}_{2}$ extraction, the $0.01 \mathrm{M}$ solution of calcium chloride has approximately the same ionic strength as an average salt concentration in many soil solutions (Houba et al. 2000).

The grain fractions $<2 \mathrm{~mm}$ were dissolved in a mineralizer at the temperature $130{ }^{\circ} \mathrm{C}$ in the $3: 1$ mixture of concentrated $\mathrm{HCl}$ and $\mathrm{HNO}_{3}$ to establish total contents (TC) of elements. Their concentrations in the solutions were determined at the certified Hydrogeochemical Laboratory at the AGH University of Science and Technology using the ICP-MS method (an Elan 6100 apparatus). The certificate No. AB 1050 has been issued in Poland by the State Accreditation Commission (Polish abbreviation PCA). The Certipur Certified Reference Material (HC69208280) was used as a standard. The analysis precision for $\mathrm{As}, \mathrm{Cd}, \mathrm{Co}$, $\mathrm{Cr}, \mathrm{Cu}, \mathrm{Ni}, \mathrm{Pb}$ and $\mathrm{Zn}$ was $10 \%$ and the accuracy $95-104 \%$. The limits of detection (LOD) and limits of quantification (LOQ) were calculated from the following equations:

$$
\begin{aligned}
& \mathrm{LOD}=X_{b}+3 S D_{b} \\
& \mathrm{LOQ}=X_{b}+10 S D_{b}
\end{aligned}
$$


Fig. 1 Location of sampling sites withing the border of Malopolska Province

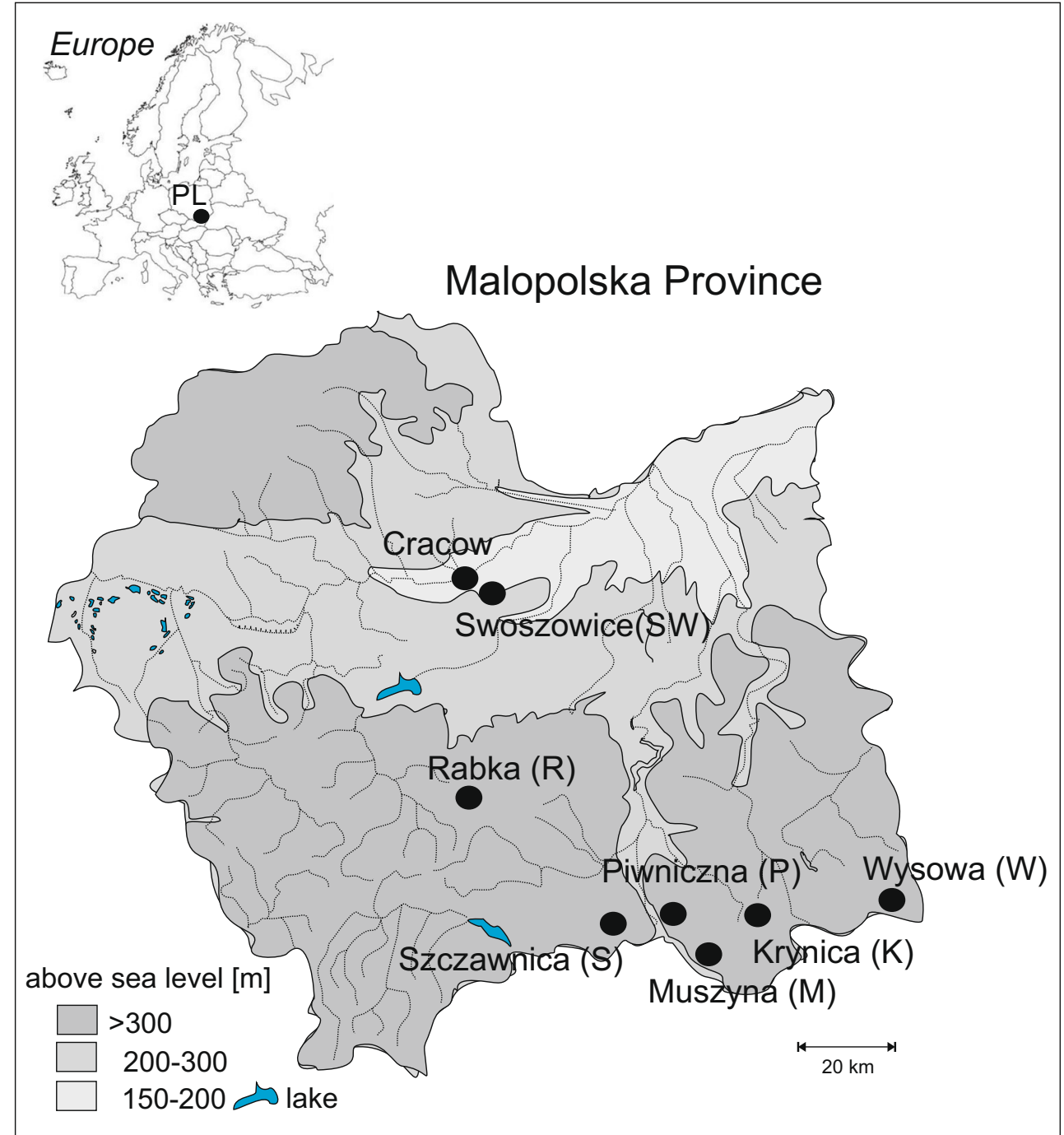

where

\section{$\mathrm{Xb}$ the mean concentration of the blank (zero concentration) sample and \\ $S D_{\mathrm{b}} \quad$ the standard deviation of the blank}

and their values are presented in Table 2 .

The model used in this study to calculated children's exposure to metals in health resorts was adapted according to the US Environmental Protection Agency (US EPA 1996, 1997). The health risk $\mathrm{HQ}_{i}$ was calculated accepting three pathways:

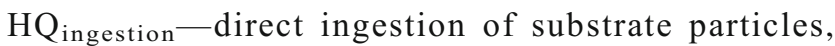

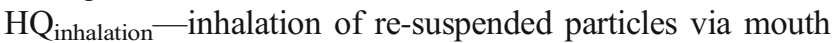

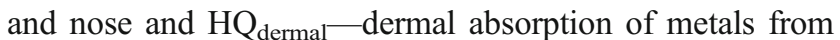
the particles adhered to an exposed skin (De Miguel et al. 2007). The health risk values: $H_{Q}$ ing, $H Q_{\text {inhal }}$ and $H_{Q_{\text {dermal }}}$ were calculated for each element as the ratio of the contact dose ( $D_{\text {ing }}, D_{\text {inhal }}$ and $D_{\text {dermal }}$, respectively) divided by the corresponding reference doses $\left(\mathrm{RfD}_{\text {ing }}, \mathrm{RfD}_{\text {inhal }}\right.$ and $\mathrm{RfD}_{\text {dermal}}$, respectively) after US EPA (2005).
The dose was calculated using the following equations (US EPA 1986):

$$
\begin{aligned}
& D_{\text {ingestion }}=C \cdot \frac{\operatorname{Ing} R \cdot \mathrm{EF} \cdot \mathrm{ED}}{\mathrm{BW} \cdot \mathrm{AT}} \cdot \mathrm{CF} 1 \\
& D_{\text {inhalation }}=C \cdot \frac{\mathrm{Inh} R \cdot \mathrm{EF} \cdot \mathrm{ED}}{\mathrm{PEF} \cdot \mathrm{BW} \cdot \mathrm{AT}} \\
& D_{\text {dermal }}=C \cdot \frac{\mathrm{SA} \cdot \mathrm{SL} \cdot \mathrm{ABS} \cdot \mathrm{EF} \cdot \mathrm{ED}}{\mathrm{BW} \cdot \mathrm{AT}} \cdot \mathrm{CF} 1
\end{aligned}
$$

where

C mean heavy metal concentration in a sample $(\mathrm{mg} / \mathrm{kg})$;

IngR conservative estimates of dust ingestion rates; for children 100 (mg per h) (US EPA 2011);

InhR inhalation rate; in this study, $1.26\left(\mathrm{~m}^{3} / \mathrm{h}\right.$, for 3 to $<6$ years old, for moderate intensity) (US EPA 2011);

EF exposure frequency; for residents accepted as 646 (h/year) after De Miguel et al. (2007), for visitors as 84 (h/year) accepting that most of children stay in the spa 
Table 1 Sampling sites and short characteristic of spas

\begin{tabular}{|c|c|c|c|c|c|c|}
\hline \multirow[t]{2}{*}{ Health resort (symbol) } & \multirow{2}{*}{$\begin{array}{l}\text { Sampling } \\
\text { site }\end{array}$} & \multicolumn{2}{|l|}{ Coordinance } & \multirow{2}{*}{$\begin{array}{l}\text { Characteristics of the } \\
\text { playground area }\end{array}$} & \multirow{2}{*}{$\begin{array}{l}\text { Number and } \\
\text { kinds of } \\
\text { medicinal } \\
\text { treatment }^{\mathrm{a}}\end{array}$} & \multirow{2}{*}{$\begin{array}{l}\text { Natural healing resources/ } \\
\text { the healing properties of } \\
\text { the climate }\end{array}$} \\
\hline & & $\mathrm{E}$ & $\mathrm{N}$ & & & \\
\hline \multirow[t]{3}{*}{ Szczawnica (S) } & $\mathrm{S} 1$ & $20^{\circ} 28^{\prime} 09.69^{\prime \prime}$ & $49^{\circ} 25^{\prime} 36.59^{\prime \prime}$ & $\begin{array}{l}\text { Private area, next to main } \\
\text { road }\end{array}$ & \multirow[t]{3}{*}{ 5: A, C, F, G, I } & \multirow{3}{*}{$\begin{array}{l}\text { Mineral water/mountain } \\
\text { climate, moderately } \\
\text { incentives, moderated } \\
\text { by forest areas (stands } \\
\text { of conifers) }\end{array}$} \\
\hline & S2 & $20^{\circ} 28^{\prime} 58.24^{\prime \prime}$ & $49^{\circ} 25^{\prime} 31.41^{\prime \prime}$ & $\begin{array}{l}\text { Solar sanatorium, next to } \\
\text { way exit }\end{array}$ & & \\
\hline & S3 & $20^{\circ} 29^{\prime} 09.37^{\prime \prime}$ & $49^{\circ} 25^{\prime} 28.94^{\prime \prime}$ & Nursery area & & \\
\hline \multirow[t]{3}{*}{ Rabka (R) } & R1 & $19^{\circ} 57^{\prime} 44.37^{\prime \prime}$ & $49^{\circ} 36^{\prime} 19.41^{\prime \prime}$ & In urban park & \multirow{3}{*}{$\begin{array}{l}\text { 6: A, D, F, G, I, } \\
\text { M }\end{array}$} & \multirow{3}{*}{$\begin{array}{l}\text { Mineral water/mountain } \\
\text { climate, moderately } \\
\text { and strongly incentives }\end{array}$} \\
\hline & $\mathrm{R} 2$ & $19^{\circ} 57^{\prime} 24.36^{\prime \prime}$ & $49^{\circ} 36^{\prime} 37.60^{\prime \prime}$ & Next to nursey & & \\
\hline & $\mathrm{R} 3$ & $19^{\circ} 57^{\prime} 16.74^{\prime \prime}$ & $49^{\circ} 36^{\prime} 37.06^{\prime \prime}$ & Next to block of flats & & \\
\hline \multirow[t]{3}{*}{ Krynica (K) } & K1 & $20^{\circ} 57^{\prime} 16.70^{\prime \prime}$ & $49^{\circ} 25^{\prime} 41.81^{\prime \prime}$ & Next to block of flats & \multirow{3}{*}{$\begin{array}{l}\text { 8: B, C, F, H, I, } \\
\quad \text { N, O, P }\end{array}$} & \multirow{3}{*}{$\begin{array}{l}\text { Mineral water/subalpine } \\
\text { climate, moderated by } \\
\text { forest areas }\end{array}$} \\
\hline & $\mathrm{K} 2$ & $20^{\circ} 55^{\prime} 50.80^{\prime \prime}$ & $49^{\circ} 24^{\prime} 37.39^{\prime \prime}$ & On hotel area & & \\
\hline & $\mathrm{K} 3$ & $20^{\circ} 56^{\prime} 45.53^{\prime \prime}$ & $49^{\circ} 2401.57^{\prime \prime}$ & Next to block of flats & & \\
\hline \multirow[t]{4}{*}{ Muszyna (M) } & M1 & $20^{\circ} 53^{\prime} 38.13^{\prime \prime}$ & $49^{\circ} 21^{\prime} 13.57^{\prime \prime}$ & $\begin{array}{l}\text { Private area, next to mail } \\
\text { road }\end{array}$ & \multirow[t]{4}{*}{ 4: C, F, H, K } & \multirow{4}{*}{$\begin{array}{l}\text { Mineral water/piedmont } \\
\text { climate, moderately } \\
\text { and strongly } \\
\text { incentives, moderated } \\
\text { by forested mountain } \\
\text { slopes }\end{array}$} \\
\hline & M2 & $20^{\circ} 53^{\prime} 16.87^{\prime \prime}$ & $49^{\circ} 21^{\prime} 00.59^{\prime \prime}$ & $\begin{array}{l}\text { Recreation area, next to } \\
\text { rope park }\end{array}$ & & \\
\hline & M3 & $20^{\circ} 53^{\prime} 34.57^{\prime \prime}$ & $49^{\circ} 21^{\prime} 06.21^{\prime \prime}$ & $\begin{array}{l}\text { Private area, next to mail } \\
\quad \text { road }\end{array}$ & & \\
\hline & M4 & $20^{\circ} 53^{\prime} 39.59^{\prime \prime}$ & $49^{\circ} 21^{\prime} 05.07^{\prime \prime}$ & Next to block of flats & & \\
\hline \multirow[t]{4}{*}{ Piwniczna (P) } & $\mathrm{P} 1$ & $20^{\circ} 43^{\prime} 03.72^{\prime \prime}$ & $49^{\circ} 26^{\prime} 25.19^{\prime \prime}$ & $\begin{array}{l}\text { In urban park, next to } \\
\text { river }\end{array}$ & \multirow[t]{4}{*}{ 4: C, F, G, H } & \multirow{4}{*}{$\begin{array}{l}\text { Mineral water/mountain } \\
\text { climate, moderately } \\
\text { and strongly incentives }\end{array}$} \\
\hline & $\mathrm{P} 2$ & $20^{\circ} 42^{\prime} 37.94^{\prime \prime}$ & $49^{\circ} 26^{\prime} 29.64^{\prime \prime}$ & Next to block of flats & & \\
\hline & P3 & $20^{\circ} 42^{\prime} 41.77^{\prime \prime}$ & $49^{\circ} 26^{\prime} 28.81^{\prime \prime}$ & Next to block of flats & & \\
\hline & P4 & $20^{\circ} 42^{\prime} 50.88^{\prime \prime}$ & $49^{\circ} 26^{\prime} 23.84^{\prime \prime}$ & $\begin{array}{l}\text { Private area, next to mail } \\
\text { road }\end{array}$ & & \\
\hline \multirow[t]{3}{*}{ Wysowa (W) } & W1 & $21^{\circ} 10^{\prime} 57.02^{\prime \prime}$ & $49^{\circ} 26^{\prime} 24.74^{\prime \prime}$ & In urban park & \multirow{3}{*}{$\begin{array}{l}\text { 10: A, B, C, F, } \\
\text { G, H, I, J, L } \\
\text { O }\end{array}$} & \multirow{3}{*}{$\begin{array}{l}\text { Mineral water/mountain } \\
\text { climate, gentle } \\
\text { incentives, moderated } \\
\text { by forest areas (beech, } \\
\text { spruce, fir) }\end{array}$} \\
\hline & W2 & $21^{\circ} 10^{\prime} 49.05^{\prime \prime}$ & $49^{\circ} 26^{\prime} 20.85^{\prime \prime}$ & In urban park & & \\
\hline & W3 & $21^{\circ} 10^{\prime} 20.64^{\prime \prime}$ & $49^{\circ} 26^{\prime} 20.14^{\prime \prime}$ & Next to block of flats & & \\
\hline \multirow[t]{2}{*}{ Swoszowice (SW) } & SW1 & $19^{\circ} 55^{\prime} 55.88^{\prime \prime}$ & $49^{\circ} 59^{\prime} 32.55^{\prime \prime}$ & Next to block of flats & \multirow[t]{2}{*}{ 5: A, B, C, L, M } & \multirow{2}{*}{$\begin{array}{l}\text { Mineral water/lowland } \\
\text { climate, moderately } \\
\text { incentives, microcli- } \\
\text { mate zone }\end{array}$} \\
\hline & SW2 & $19^{\circ} 56^{\prime} 43.16^{\prime \prime}$ & $49^{\circ} 59^{\prime} 39.94^{\prime \prime}$ & Next to nursey & & \\
\hline
\end{tabular}

${ }^{\text {a }}$ Treatment of diseases: $A$ orthopaedic trauma, $B$ nervous system, $C$ rheumatologic, $D$ cardiology and hypertension, $E$ peripheral vascular, $F$ upper respiratory tract, $G$ lower respiratory tract, $H$ digestive system, $I$ diabetes, $J$ obesity, $K$ endocrine, $L$ osteoporosis, $M$ skin, $N$ feminine, $O$ kidney and urinary tract, $P$ blood and cardiovascular system, $R$ eye and appendages of an eye

for 3 weeks and use playgrounds for $4 \mathrm{~h}$ per day; many of them spend every year holidays in the same child health resort;

ED exposure duration; for younger children 3 (years) and older ones 6 (years);

BW body mass; for children 3 years old $15(\mathrm{~kg})$, for those 6 years old $20(\mathrm{~kg})$ (mean values, US EPA 2011);

AT averaging time. In the case of non-carcinogens: for 3 year-old children, its value is $3 \times 365=1095$ (days), for 6-year-old children, its value is $6 \times 365=2190$ (days), while in the case of carcinogens, its value is $70 \times 365=25,550$ (days);
SA exposed skin area, $2800\left(\mathrm{~cm}^{2}\right)$ (recommended values for mean solid adherence to skin (US EPA 2011)

SL skin adherence factor, $0.07\left(\mathrm{mg} / \mathrm{cm}^{2}\right.$ per h) (after De Miguel et al. 2007);

ABS dermal absorption factor, 0.001 (all the elements except As, for As 0.03) (after De Miguel et al. 2007);

PEF particle emission factor, $6.8 \mathrm{E}+08\left(\mathrm{~m}^{3} / \mathrm{kg}\right)($ after De Miguel et al. 2007);

CF1 unit conversion factor of $10^{-6}$.

The total hazard index $(H I)$ was calculated as a sum of $\mathrm{HQ}_{\text {ing }}, \mathrm{HQ}_{\text {inhal }}$ and $\mathrm{HQ}_{\text {dermal }}$ values. It is accepted that at the 


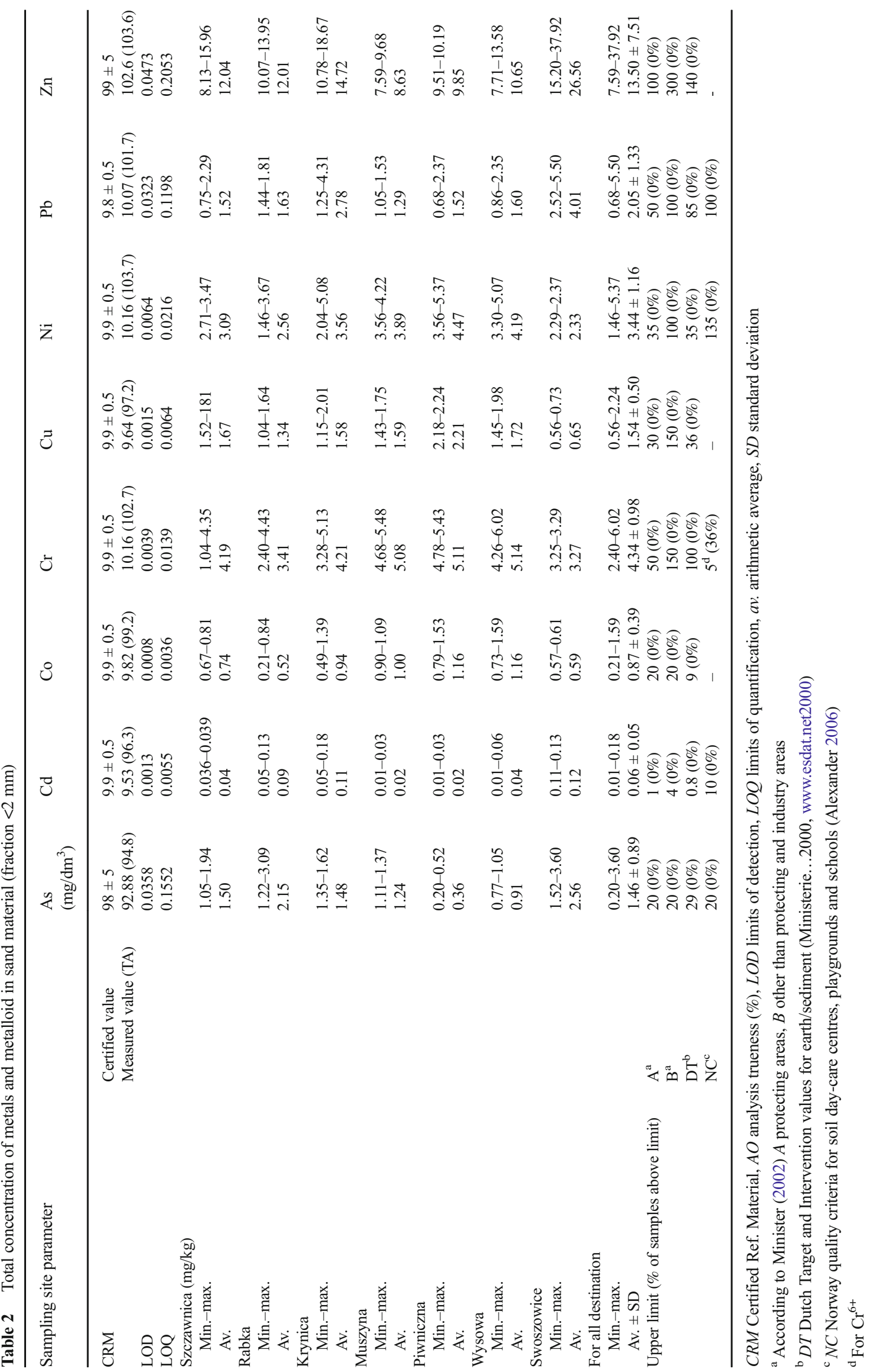


$H I \leq 1$ adverse health effects are of a low probability to occur, at the $H I>1$, negative health effects are probable, while the $H I>10$ values are a sign of a high exposure and a highly possible chronic health risk caused by a toxic factor(s).

For carcinogens, their doses were multiplied by the respective slope factors $(\mathrm{SF})$ to produce a level of the cancer risk. The toxicity values used in the analysis were taken from US EPA (2005). For Pb, the reference doses are those contained in the World Health Organization's Guidelines for Drinking Water Quality (WHO 1993). The toxicity values of dermal absorption were taken from IRIS (US EPA 2005): the oral reference doses are multiplied while the slope factors divided by a gastrointestinal absorption factor to yield the corresponding dermal values.

The stations that measure the amounts of $\mathrm{PM}_{10}, \mathrm{PM}_{2.5}$ and the metals that the samples contain are only occasionally situated in the parks of the spa resorts of Poland. In the case presented, neither of the parks considered in the report has such a station. An interpolation to the park areas of the data obtained in other sites of the spa (open markets, streets, major thoroughfares, etc.) would have been burdened with much higher errors than our calculation of a risk attributed to inhaling airborne particles. This is a way to estimate risk from inhalation; the older method (US EPA 2005), based on IR and $\mathrm{BW}$, was chosen.

Statistical calculations and data presentations were conducted with the Statistica ver. 10 and Excel applications. The group analyses were based on variables (concentrations of elements) characterizing the objects considered (i.e. parks) and allowed distinguishing the groups (clusters), inside which the parameters selected are more similar within the given group than to the parameters within other groups. This type of analysis allows to establishing whether the groups reveal any regularity (correlation), and as a result, it reduces the databases to the averages calculated for specific groups. The Ward method is an analysis of a variance problem, based on minimizing totals of square deviations within the groups (clusters). The method accumulates into clusters the cases with minimum diversifications. The differences between means were detected by Turkey's test at a significance level of 0.05 .

\section{Results of investigations}

\section{Mineral and chemical composition of sands}

Each of the general samples is mostly, in around 90\%, composed of oval, well-rounded quartz grains. Their sizes measured under an optical Nikon Eclipse 50i-POL microscope range between 0.1 and $0.5 \mathrm{~mm}$, with a distinct prevalence of the grain fraction $0.3-0.5 \mathrm{~mm}$ (Fig. 2). The quartz grains are highly transparent and colourless or with a delicate milky brown tint. Opaque grains make up 7-8\% and represent probably amphiboles and pyroxenes. Greenish grains of olivines occur occasionally. The list is supplemented by micas, occurring as fine, disintegrating flakes of both muscovite and biotite.

The As contents range from 0.2 to $3.6 \mathrm{mg} / \mathrm{kg}$ (Table 2) and those of Cd from 0.01 to $0.18 \mathrm{mg} / \mathrm{kg}$. The contents of Co, Cr, $\mathrm{Cu}$ and $\mathrm{Ni}$ are comparable: $0.21-1.59,2.40-6.02,0.56-2.24$ and $1.46-5.37 \mathrm{mg} / \mathrm{kg}$, respectively. Zinc occurs at distinctly higher quantities, from 7.59 to $38 \mathrm{mg} / \mathrm{kg}$.

The highest $\mathrm{TC}$ values of $\mathrm{As}, \mathrm{Cd}, \mathrm{Pb}$ and $\mathrm{Zn}$ occur in Swoszowice (Fig. 1), while those of $\mathrm{Co}, \mathrm{Cu}$ and $\mathrm{Ni}$ (1.16, 2.21 and $4.47 \mathrm{mg} / \mathrm{kg}$, respectively) in Piwniczna. The highest TC of Cr (range 4.26-6.02, mean $5.14 \mathrm{mg} / \mathrm{kg}$ ) was determined in Wysowa. The distribution of the lowest metal quantities is as follows: of $\mathrm{Cd}, \mathrm{Pb}$ and $\mathrm{Zn}$ in Muszyna, of Co in Rabka, while of $\mathrm{Cr}, \mathrm{Cu}$ and $\mathrm{Ni}$ in Swoszowice.

Owing to the lack of standards pertaining to the content of heavy metals in sands of the playground sandboxes, the results were compared with the metal standards for soils and sediments effective in several European countries. In the Polish legislation (Minister 2002), three types of areas have been distinguished: protected (group A), industrial (group C) and others than protected and industrial (group B). All the results obtained for the sands of seven Polish spas do not exceed the permissible values of the group A soils, i.e. As 20, Cd 1, Co 20, $\mathrm{Cu} 30, \mathrm{~Pb} 50, \mathrm{Zn} \mathrm{100,} \mathrm{Cr} 50$ and Ni $35 \mathrm{mg} / \mathrm{kg}$. The results are also lower than the respective values of the B group soils.

Different permissible contents of heavy metals in grounds, soils and other sediments can be found in almost all
Fig. 2 Images of the test material seen under an optical microscope. $K$ sample please change "form" to "from" - 3 times Krynica, $S$ sample from Szczawnica, $S W$ sample from Swoszowice
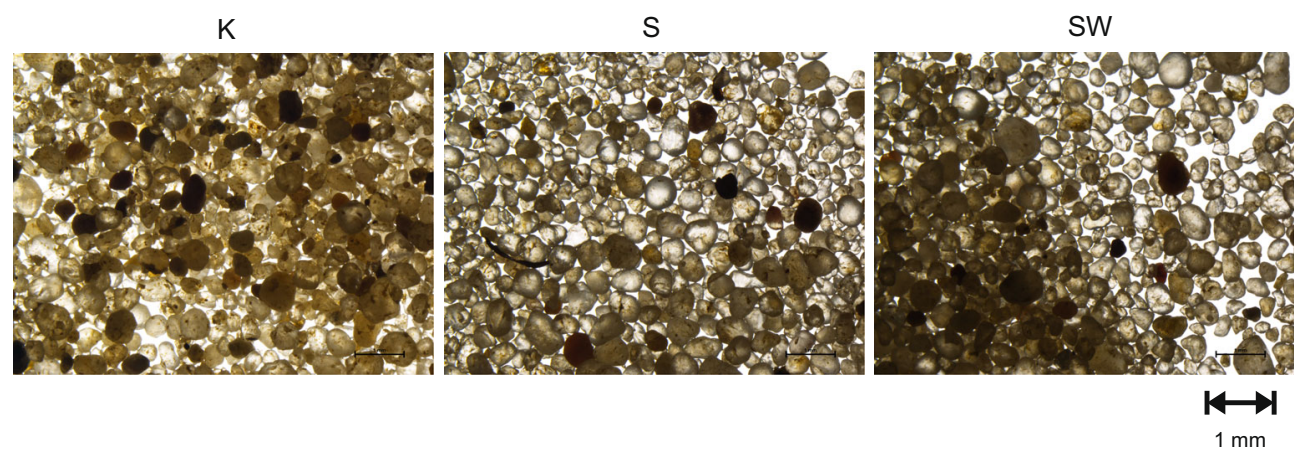
environmental regulations of various countries. Distinctly more restrictive are Dutch standards (Ministerie 2000): their Cd and Co permissible limits are much lower, while those of $\mathrm{Cr}, \mathrm{Pb}$ and $\mathrm{Zn}$ slightly lower than the Polish equivalents of the group A soils; the only comparable are the permissible values of $\mathrm{As}, \mathrm{Cu}$ and Ni (Table 2). Thus, none of the sand samples of the spas exceeds the $\mathrm{As}, \mathrm{Cr}, \mathrm{Cd}, \mathrm{Pb}, \mathrm{Ni}, \mathrm{Co}, \mathrm{Zn}$ and $\mathrm{Cu}$ limits of the Dutch Target (Ministerie...2000). The Norwegian standards of the soils occurring in playgrounds and in the green areas around schools (Alexander 2006) are distinctly less restrictive than the Polish ones in the case of $\mathrm{Cd}, \mathrm{Ni}$ and $\mathrm{Pb}$ contents, but are much higher in the case of $\mathrm{Cr}$. No permissible values of $\mathrm{Co}, \mathrm{Cu}$ and Zn have been set in Norway. Classifying our samples according to the Norwegian requirements, the contents of $\mathrm{As}, \mathrm{Cd}, \mathrm{Pb}$ and $\mathrm{Ni}$ are below the upper limits, but $36 \%$ samples exceed the stipulated upper content of $5 \mathrm{mg} / \mathrm{kg}$ of $\mathrm{Cr}$.

The sand samples may also be assessed using the guidelines of the IUNG-PIB (Institute of Soil Science and Plant Cultivation) in Puławy, Poland (Kabata-Pendias et al. 1993). The IUNG classifies the soils into six groups on the basis of their contamination, from class 0 - the quantity of an element corresponds to its natural content - to class VI-soils of a very high degree of pollution. According to this classification, the samples of sands belong to the category of materials nonpolluted with $\mathrm{Pb}, \mathrm{Zn}, \mathrm{Cu}, \mathrm{Ni}$ and $\mathrm{Cd}$, which means that the contents of these elements fall into the range of natural values. The limits of the remaining metals, i.e. As, $\mathrm{Co}$ and $\mathrm{Cr}$, have not been specified in the IUNG guidelines.

\section{Sources of heavy metals in sandboxes}

The metals included into the group of harmful elements may usually be ascribed into several subgroups, each of them of the common genesis, i.e. generated by the same emitter type. The sources of the metals present in the sands have been established by calculating correlation coefficients of these elements (Table 3 ) and conducting the cluster analysis (Fig. 3).
The correlation coefficients $(r)$ point to a high dependence in the range $0.5 \leq r<0.7$ of three pairs: $\mathrm{Cd}-\mathrm{As}, \mathrm{Cd}-\mathrm{Pb}$ and $\mathrm{Cd}-$ $\mathrm{Zn}$ and a very high correlation of $0.7 \leq r<0.9$ of five pairs: $\mathrm{Cu}-\mathrm{Co}, \mathrm{Cu}-\mathrm{Cr}, \mathrm{Cu}-\mathrm{Ni}$, As-Ni and $\mathrm{Cr}-\mathrm{Pb}$. Almost fully correlated $(0.9 \leq r<1)$ are $\mathrm{Co}-\mathrm{Cr}, \mathrm{Co}-\mathrm{Ni}, \mathrm{Cr}-\mathrm{Ni}$ and $\mathrm{Pb}-\mathrm{Zn}$.

The dendrogram (Fig. 3) indicates two clusters, called further groups I and II. Into the group I belong $\mathrm{As}, \mathrm{Co}, \mathrm{Cu}, \mathrm{Cd}$ and $\mathrm{Pb}$ and into the group II two elements, $\mathrm{Cr}$ and $\mathrm{Ni}$. The group I is composed of the elements associated mainly with the low emissions and combustion of motor fuels. Elevated quantities of As, Cd and Co occur in biolites (fossil fuels) and, according to Kabata-Pendias et al. (1993), amount to 5-15, $0.7-1.3$ and $5-40 \mathrm{mg} / \mathrm{kg}$, respectively. In the course of burning, mainly in households and small boiler houses, these elements find the way to the atmosphere from which are deposited on the ground surface. Another group of metals includes elements used for production of vehicles, mainly in manufacturing of protective coats. More important and being in a common use are nickel-chromium coats with anticorrosive properties. Relatively elastic, they show good adhesion to steel or copper parts. Since quickly becoming matt not only when used on the road but due to the normal atmospheric exposure, they are covered by an additional, lustre-providing chromium layer. Also all moving motor parts due to their standard wear are sources of a contamination in the form of fine metal-bearing particles that accumulate in various components of the environment. The most obvious are such wear products of brake discs and shoes, manufactured-among others - with the use of copper and steel fibres and graphite, and also of vehicle tires, not only rubber itself but also tyre metallic mesh reinforcements or wheel rings.

\section{Sandboxes as a possible source of metals polluting the environment}

Two environmental parameters of heavy metals contained in the sand, their mobility and availability to soil organisms and to
Table 3 Correlation coefficients $\left(r_{x y}\right)$ calculated for the concentration of metals and metalloid in sands material (fraction $<2 \mathrm{~mm}$ )

\begin{tabular}{|c|c|c|c|c|c|c|c|}
\hline Element & $\mathrm{Cd}$ & $\mathrm{Co}$ & $\mathrm{Cr}$ & $\mathrm{Cu}$ & $\mathrm{Ni}$ & $\mathrm{Pb}$ & $\mathrm{Zn}$ \\
\hline As & $0.60 * * *$ & $-0.27 *$ & $-0.35 * * *$ & -0.59 & $0.72 * * *$ & 0.15 & $0.12 * * *$ \\
\hline $\mathrm{Cd}$ & - & $-0.53 *$ & $-0.60 * * *$ & $-0.64 * * *$ & $-0.57 * * *$ & $0.62 * * *$ & $\mathbf{0 . 5 3} * * *$ \\
\hline Co & & - & $0.93 * * *$ & $0.72 * * *$ & $0.98 * * *$ & $-0.23 * *$ & $-0.33 * * *$ \\
\hline $\mathrm{Cr}$ & & & - & $0.82 * * *$ & $0.95^{*}$ & $0.89 * * *$ & $-0.47 * * *$ \\
\hline $\mathrm{Cu}$ & & & & - & $0.80^{* * * *}$ & -0.51 & $-0.55^{* * * *}$ \\
\hline $\mathrm{Ni}$ & & & & & - & -0.38 & $-0.45^{* * *}$ \\
\hline $\mathrm{Pb}$ & & & & & & - & $0.91 * * *$ \\
\hline
\end{tabular}

Bold values high correlation $(0.5 \leq r<0.7)$, italic bold values indicate very high correlation $(0.7 \leq r<0.9)$, and italic values indicate the correlation almost full $(0.9 \leq r<1)$

Differences between the content, statistically significant at $* p \leq 0.05 ; * * p \leq 0.01 ; * * * \leq 0.001$ 
Fig. 3 Dendrogram for specified element content in sand samples from spas
Ward's methods

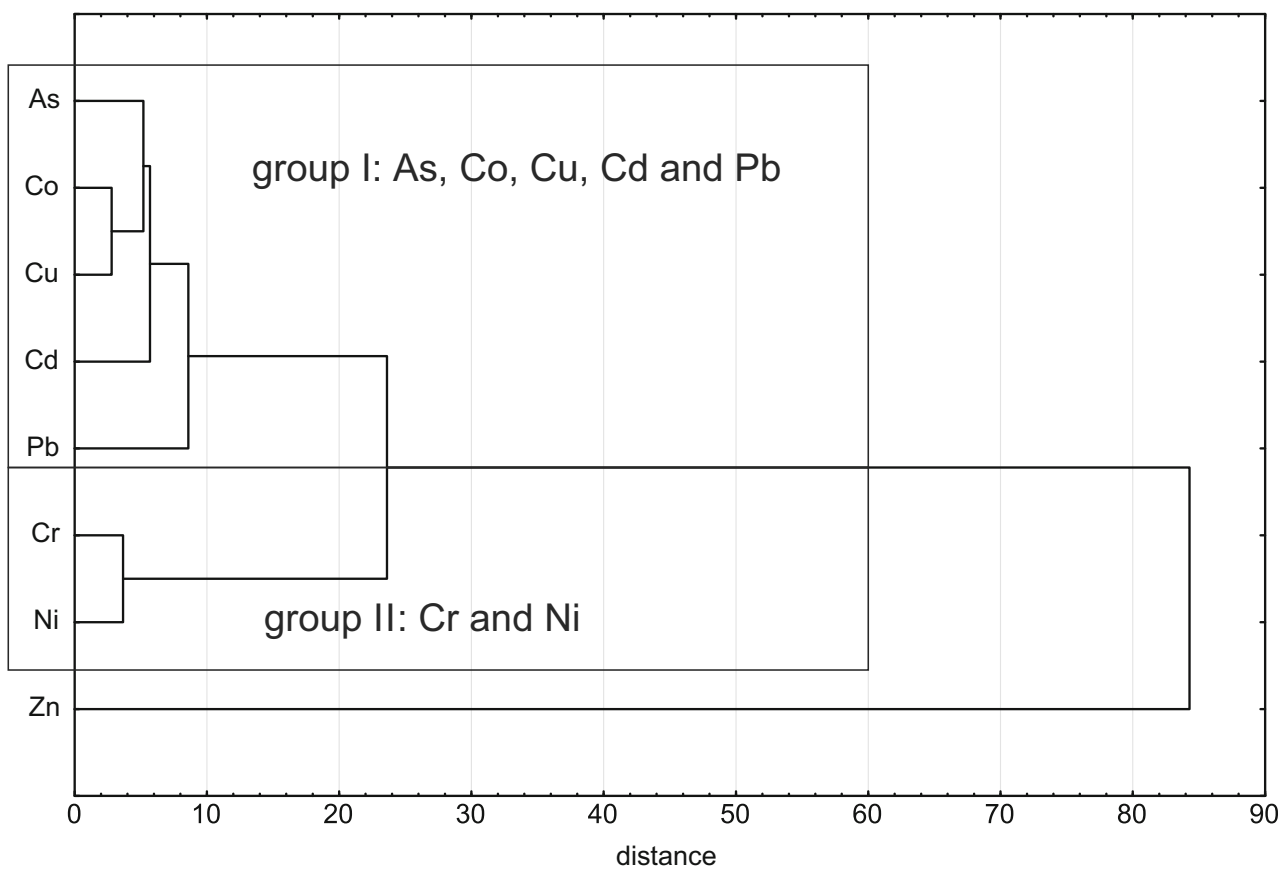

plants, were determined with the use of extraction methods (Table 4). Water extracts a part of metals weakly bound to solid particles, mainly the metals at the exchangeable positions. Metals in the form of ions are highly mobile in rainfall and surface waters; moreover, $100 \%$ of them can penetrate cellular membranes. The extraction with the $0.01 \mathrm{M} \mathrm{CaCl}_{2}$ and $0.02 \mathrm{M}$ EDTA releases the metals that are mostly available to living organisms. The extractions with the not buffered solution of $\mathrm{CaCl}_{2}$ and with solutions of complexing compounds (EDTA) were applied to determine hazards to the water-soil environment, mainly to surface waters, soil-living species and plants, caused by the metals present in playgrounds (Karczewska et al. 2009).

Of the metals considered, water leaching removes on the average $13 \%$ of the TC of Cd, slightly less - around $7 \%$ TCs of $\mathrm{As}$ and $\mathrm{Cu}$ - and lower quantities - around 4\% TC of Co and $\mathrm{Zn}, 3 \% \mathrm{TC}$ of $\mathrm{Cr}$ and around $2 \% \mathrm{TC}$ of $\mathrm{Ni}$. The lowest mobility in water extracts was determined for $\mathrm{Pb}$, whose quantities ranged from 0.01 to $3.8 \%$ TC with an average of $0.7 \%$.

Comparing the concentrations of the metals in the water extracts with the upper limits of metals in potable waters, the WHO (1993) criteria for $\mathrm{Cr}, \mathrm{Cu}, \mathrm{Ni}, \mathrm{Pb}$ and $\mathrm{Zn}(0.05,2.00$, $0.02,0.01$ and $5 \mathrm{mg} / \mathrm{dm}^{3}$, respectively) are almost fully satisfied. Only does one result exceed the limit of $0.01 \mathrm{mg}$ As per $1 \mathrm{dm}^{3} \mathrm{As}$, and 16 samples do not meet the limit of $0.002 \mathrm{mg}$ Co per $1 \mathrm{dm}^{3}$.

The TCs of eluents extracted with $0.01 \mathrm{M} \mathrm{CaCl}_{2}$ from solid samples are in most cases higher than those water-leached (Table 4). The highest availabilities to living organisms reveal As and Cd: in the case of As in the range $0.1-81.2 \%$ TC with an average of $8.3 \%$ and in the case of $\mathrm{Cd} 0.4-62.9 \%$ TC with an average of $22.6 \%$. Five elements have their eluent values significantly lower: below $23 \% \mathrm{TC}$ of $\mathrm{Pb}$ (average $2.9 \%$ ), below $16 \%$ TC of Co (average 7.0\%), below $13 \%$ TC of Cu and $\mathrm{Zn}$ (average 6.8 and $5.6 \%$, respectively) and considerably less of Ni below 4.4\% TC (average 2.3\%). The last metal - chromium - was extracted with $0.01 \mathrm{M} \mathrm{CaCl}_{2}$ in quantities from 0.02 to $5.7 \% \mathrm{TC}$.

The TCs of eluents extracted with $0.02 \mathrm{M}$ EDTA from solid samples are in most cases considerably higher than those water-leached ones and higher than those extracted with $0.01 \mathrm{M} \mathrm{CaCl}_{2}$ (Table 4). The highest availabilities for plants reveal As and Cd: in the case of As in the range 28-100\% TC with an average of $82 \%$ and in the case of $\mathrm{Cd} 15-100 \% \mathrm{TC}$ with an average of $60 \%$. Five elements have their eluent values significantly lower: below $78 \% \mathrm{TC}$ of $\mathrm{Pb}$ (average $21 \%$ ), below $38 \%$ TC of Cu (average 15\%), below $31 \% \mathrm{TC}$ of $\mathrm{Zn}$ (average 12\%), below 29\% TC of Co (average $8 \%$ ) and considerably less of $\mathrm{Ni}-2-9 \%$ TC (average $4 \%$ ). The quantities of the eighth metal - chromium extracted with $0.02 \mathrm{M}$ EDTA (0.2-2\% TC) - are lower than those leached with water (1.2-5.4\% TC). It is a result of two possible forms of chromium that can occur in the environment. The $\mathrm{Cr}^{6+}$ compounds are soluble in water, mobile and, thus, harmful to plants and animals. The $\mathrm{Cr}^{3+}$ compounds are hardly soluble and, moreover, fast immobilized by proteins and stopped on cellular membranes (Kabata-Pendias and Mukherjee 2007a).

For comparative purposes, Table 4 presents contents of the elements considered in selected land-living organism, i.e. plants (mainly grass species) and animals, reported by Kabata-Pendias and Pendias (1999). The data are supplemented with the respective toxic data and permissible limits. The 
Table 4 Extraction of EDTA and $0.01 \mathrm{M} \mathrm{CaCl}_{2}$ solution and water leaching of metal (as a \% of total content from sand material) (fraction $<2 \mathrm{~mm}$ )

\begin{tabular}{|c|c|c|c|c|c|c|c|c|c|}
\hline \multicolumn{2}{|c|}{ Sampling site/parameter } & $\begin{array}{l}\text { As } \\
(\% \text { of TC) }\end{array}$ & $\mathrm{Cd}$ & Co & $\mathrm{Cr}$ & $\mathrm{Cu}$ & $\mathrm{Ni}$ & $\mathrm{Pb}$ & $\mathrm{Zn}$ \\
\hline \multicolumn{10}{|l|}{ Szczawnica } \\
\hline \multicolumn{2}{|c|}{ Water leaching/min.-max. } & $0.01-0.20$ & $0.2-30.2$ & $0.5-5.6$ & $4.7-5.4$ & $6.1-8.2$ & $2.8-4.0$ & $0.01-0.3$ & $4.5-5.0$ \\
\hline \multicolumn{2}{|c|}{$0.01 \mathrm{M} \mathrm{CaCl}_{2}$ extraction/min.-max. } & $0.19-0.21$ & $8.7-31.0$ & $0.1-5.5$ & $0.3-5.7$ & $0.4-8.4$ & $0.2-4.4$ & $13.0-25.9$ & $0.7-5.9$ \\
\hline \multicolumn{2}{|c|}{ EDTA extraction/min.-max. } & $58-100$ & $41-90$ & $4-10$ & $0.4-0.5$ & $7-20$ & $3-5$ & $13-26$ & $6-13$ \\
\hline \multicolumn{10}{|c|}{ Rabka } \\
\hline \multicolumn{2}{|c|}{ Water leaching/min.-max. } & $0.01-0.01$ & $0.2-2.4$ & $2.9-13.4$ & $2.4-4.1$ & $4.4-12.1$ & $1.2-1.4$ & $0.9-3.4$ & $5.2-11.8$ \\
\hline \multicolumn{2}{|c|}{$0.01 \mathrm{M} \mathrm{CaCl}_{2}$ extraction $/ \mathrm{min}$ - $\max$. } & $0.08-0.11$ & $4.5-16.9$ & $1.2-15.9$ & $0.02-4.2$ & $0.7-12.7$ & $0.3-1.9$ & $29.9-78.4$ & $0.6-12.4$ \\
\hline \multicolumn{2}{|c|}{ EDTA extraction/min.-max. } & $40-99$ & $36-43$ & $7-29$ & $1-2$ & $8-19$ & $4-9$ & $30-78$ & $21-31$ \\
\hline \multicolumn{10}{|c|}{ Krynica } \\
\hline \multicolumn{2}{|c|}{ Water leaching/min.--max. } & $5.1-5.5$ & $0.1-7.3$ & $3.1-3.3$ & $1.7-3.4$ & $6.5-7.0$ & $1.0-2.3$ & $0.1-0.2$ & $1.3-3.7$ \\
\hline \multicolumn{2}{|c|}{$0.01 \mathrm{M} \mathrm{CaCl}_{2}$ extraction/min.-max. } & $5.1-5.1$ & $1.9-7.1$ & $0.2-3.4$ & $0.2-3.3$ & $0.1-7.5$ & $0.2-2.3$ & $7.4-22.4$ & $0.6-3.9$ \\
\hline \multicolumn{2}{|c|}{ EDTA extraction/min.-max. } & $69-89$ & $15-73$ & $6-7$ & $0.6-0.7$ & $20-23$ & $2-4$ & $7-22$ & $7-8$ \\
\hline \multicolumn{10}{|c|}{ Muszyna } \\
\hline \multicolumn{2}{|c|}{ Water leaching/min.--max. } & $0.01-3.8$ & $1.0-8.6$ & $4.4-4.5$ & $3.7-4.1$ & $5.0-7.8$ & $2.9-3.1$ & $0.01-0.02$ & $5.7-6.2$ \\
\hline \multicolumn{2}{|c|}{$0.01 \mathrm{M} \mathrm{CaCl}_{2}$ extraction/min.-max. } & $0.21-5.2$ & $10.3-24.7$ & $0.3-4.5$ & $0.2-4.3$ & $0.7-7.7$ & $0.3-3.5$ & $4.1-7.7$ & $1.4-7.59$ \\
\hline \multicolumn{2}{|c|}{ EDTA extraction/min.-max. } & $84-100$ & $46-100$ & $2-3$ & $0.2-0.5$ & $7-10$ & $2.2-2.5$ & $4-10$ & $8-9$ \\
\hline \multicolumn{10}{|c|}{ Piwniczna } \\
\hline \multicolumn{2}{|c|}{ Water leaching/min.-max. } & $0.01-76.7$ & $13.3-54.7$ & $2.1-2.8$ & $1.2-2.3$ & $1.9-3.2$ & $0.7-1.5$ & $0.01-0.02$ & $0.4-0.7$ \\
\hline \multicolumn{2}{|c|}{$0.01 \mathrm{M} \mathrm{CaCl}_{2}$ extraction/min.-max. } & $0.72-81.2$ & $17.5-45.9$ & $0.3-3.4$ & $0.1-2.2$ & $0.5-3.5$ & $0.3-1.7$ & $0.3-15.8$ & $0.6-1.4$ \\
\hline \multicolumn{2}{|c|}{ EDTA extraction/min.-max. } & 100 & $69-100$ & $3-5$ & $0.5-0.6$ & $5-11$ & $2.4-2.6$ & $13-16$ & $8-14$ \\
\hline \multicolumn{10}{|c|}{ Wysowa } \\
\hline \multicolumn{2}{|c|}{ Water leaching/min.-max. } & $0.01-1.9$ & $8.4-60.0$ & $2.2-5.0$ & $3.2-4.0$ & $5.6-5.8$ & $2.3-2.6$ & $0.01-0.03$ & $0.8-1.4$ \\
\hline \multicolumn{2}{|c|}{$0.01 \mathrm{M} \mathrm{CaCl}_{2}$ extraction/min.-max. } & $0.15-2.4$ & $0.4-62.9$ & $0.6-5.8$ & $0.1-4.2$ & $0.70-6.8$ & $0.1-2.4$ & $1.5-2.1$ & $0.5-0.5$ \\
\hline EDTA extraction $/ \mathrm{m}$ & in. $-\max$. & 100 & $44-100$ & $4-7$ & $0.2-0.5$ & $8-9$ & $2.7-2.9$ & $4-14$ & $6-7$ \\
\hline Swoszowice & & & & & & & & & \\
\hline Water leaching/min & $-\max$ & $0.01-0.02$ & $0.2-1.5$ & $6.0-6.5$ & $2.0-3.9$ & $11.3-11.9$ & $1.5-3.2$ & $1.7-3.8$ & $3.5-7.3$ \\
\hline $0.01 \mathrm{M} \mathrm{CaCl}_{2}$ extrc & ction/min.-max. & $0.08-0.16$ & $0.8-1.9$ & $0.2-7.8$ & $0.1-4.1$ & $2.1-12.2$ & $0.1-4.1$ & $0.1-4.3$ & $0.7-7.4$ \\
\hline EDTA extraction $/ \mathrm{m}$ & in. $-\max$ & $28-78$ & $33-45$ & $9-16$ & $0.7-0.8$ & $33-38$ & $4-8$ & $23-32$ & $12-14$ \\
\hline For all destination & & & & & & & & & \\
\hline Water leaching/min & $-\max$. & $0.01-77$ & $0.1-60.0$ & $0.5-13.4$ & $1.2-5.4$ & $1.9-12.1$ & $0.7-4.0$ & $0.01-3.8$ & $0.4-11.8$ \\
\hline av. & & 6.7 & 13.4 & 4.4 & 3.3 & 6.9 & 2.2 & 0.7 & 4.1 \\
\hline $0.01 \mathrm{M} \mathrm{CaCl}_{2}$ extra & ction/min.-max. & $0.1-81.2$ & $0.4-62.9$ & $0.1-15.9$ & $0.02-5.7$ & $0.1-12.7$ & $0.1-4.4$ & $0.1-22.4$ & $0.5-12.4$ \\
\hline av. & & 8.3 & 22.6 & 7.0 & 4.2 & 6.8 & 2.3 & 2.9 & 5.6 \\
\hline EDTA extraction/m & in.- $-\max$. & $28-100$ & $15-100$ & $2-29$ & $0.2-2$ & $5-38$ & $2-9$ & $4-78$ & $6-31$ \\
\hline av. (in $\mathrm{mg} / \mathrm{kg}$ ) & & $82(1.20)$ & $60(0.04)$ & $8(0.07)$ & $0.7(0.02)$ & $15(0.22)$ & $4(0.14)$ & $21(0.47)$ & $12(1.45)$ \\
\hline Plants $^{1} \quad(\mathrm{mg} / \mathrm{kg})$ & Content in grass & $0.23-0.33$ & $0.05-0.6$ & $0.03-0.12$ & $0.6-3$ & $4-10$ & $0.4-1.7$ & $0.4-4.5$ & $12-72$ \\
\hline & Toxic level & $>5$ & - & $15-50$ & $5-30$ & - & $10-100$ & $30-300$ & $100-400$ \\
\hline & Fodder plants for animals & $<50$ & $<0.5$ & 0.05 & 3000 & $5-8$ & $50-300$ & $<30$ & $<200$ \\
\hline Animals ${ }^{1}$ & Content in different land species & $<1.5$ & $0.1-1.5$ & $<0.5$ & $0.02-1.5$ & $1-20$ & $1-3$ & $0.2-2$ & $10-200$ \\
\hline
\end{tabular}

min. minimum, max. maximum, av. arithmetic average, “-” no data

${ }^{1}$ According Kabata-Pendias et al. (1999)

amounts of elements extracted with the $0.02 \mathrm{M}$ solution of EDTA compared to the figures given of Kabata-Pendias and Pendias (1999) indicate the metals contained in the sands of the sandboxes not to be harmful to surrounding fauna and flora.

\section{Health risk of children}

It is estimated that the daily intake of dirt by children via the digestive tract ranges between 39 and $270 \mathrm{mg}$, which is caused mainly by frequent putting dirty hands into their mouths, particularly when playing (Ljung et al. 2007). This behaviour may generate a specific exposure of children to poisoning with heavy metals and other chemical or microbiological components present among, on or within soil particles or sand grains.
This threat is aggravated by a significantly higher index of metal absorption by children than by adults (US EPA 1986). Assuming $2 \mathrm{~h}$ daily that children spend in playgrounds and an accidental ingestion of sand grains of sandboxes, the authors calculated on the basis of the TC determinations the average daily doses $\left[D_{\text {ing }}, D_{\text {inhal }}, D_{\text {dermal }}\right.$, for calculation see Eqs. (3$5)]$ and the hazard quotients $\left(\mathrm{HQ}_{\text {ing, }}, \mathrm{HQ}_{\text {inhal }}, \mathrm{HQ}_{\text {dermal }}\right)$ of children 3 years old (accepting an average body mass of $15 \mathrm{~kg}$ ) and 6 years old (accepting an average body mass of $20 \mathrm{~kg}$ ). The reference doses (RfD) and slope factors (SF) were taken from IRIS (US EPA 2005) except those of $\mathrm{Pb}$, for which the reference dose was calculated as a percent of the PTWI (permitted tolerable weekly intake) according to WHO (1993).

Besides the age groups, calculations of three HQ indexes (for non-carcinogens) and the risk index (for carcinogens) have 
been made distinguishing two groups of children: those permanently living in the spas (called residents) and those coming to the spas to spend usually 3-month-long recuperating or treating periods (called visitors). The children of both age groups of the residents and visitors alike are endangered mainly by metals entering their organisms due to the ingestion path: the $\mathrm{HQ}_{\text {ing }}$ indexes for all the elements considered are distinctly higher than the $\mathrm{HQ}_{\text {dermal }}$ and $\mathrm{HQ}_{\text {inhal }}$ indexes (Table 5). Cobalt is the single exception: its highest $\mathrm{HQ}_{\text {ing }}$ index is followed first by the $\mathrm{HQ}_{\text {inhal }}$ index and only then by the $\mathrm{HQ}_{\text {dermal }}$ one.

The highest $\mathrm{HQ}_{\text {ing }}$ indexes are those of As and $\mathrm{Cr}$. For both age groups ( 3 and 6 years olds), they are $5.74 \mathrm{E}-02$ and $1.71 \mathrm{E}$ -02 , respectively, for residents, while $4.31 \mathrm{E}-02$ and $1.28 \mathrm{E}-02$, respectively, for visitors. The difference (larger figures) for the elder children results simply from their higher body mass. The values of the $\mathrm{HQ}_{\text {ing }}$ indexes of the remaining metals are lower than those of As and $\mathrm{Cr}$; thus, the decreasing sequence of the elements is $\mathrm{As}>\mathrm{Cr}>\mathrm{Pb}>\mathrm{Ni}>\mathrm{Cd}>\mathrm{Zn}>\mathrm{Co}>\mathrm{Cu}$. Within the group of the visitors, the $\mathrm{HQ}_{\text {ing }}$ is distinctly lower and ranges from 7.47E- 03 of As to $5.91 \mathrm{E}-05$ of $\mathrm{Cu}$ for the children 3 years old, while from $5.60 \mathrm{E}-03$ of As to $4.43 \mathrm{E}-05$ of $\mathrm{Cu}$ for the children 6 years old.

Considering the dermal path of children exposure, the relatively highest are the $\mathrm{HQ}_{\text {dermal }}$ indexes of As: $8.24 \mathrm{E}-03$ and $6.18 \mathrm{E}-03$ for the 3 and 6 years olds, respectively. In the case of the remaining elements, they decrease in the sequence $\mathrm{As}>\mathrm{Cr}>\mathrm{Cd}>\mathrm{Pb}>\mathrm{Ni}>\mathrm{Zn}>\mathrm{Cu}>\mathrm{Co}$, which differs from the sequence established for $\mathrm{HQ}_{\text {dermal }}$. Comparing the $\mathrm{HQ}_{\text {dermal }}$ values of the residents and the visitors, the figures for the visitors are about one order of magnitude lower due obviously to a shorter exposure.

The contribution of inhaling is almost of the lowest health risk for almost all the metals considered. The highest $\mathrm{HQ}_{\text {inahl }}$ indexes are in the case of Co: being 3.17E- 05 and $4.13 \mathrm{E}-06$ for the 3year-old residents and the visitors, respectively, and $2.38 \mathrm{E}-05$ and $3.09 \mathrm{E}-06$ for the 6-year-old residents and visitors, respectively. The $\mathrm{HQ}_{\text {inahl }}$ indexes of $\mathrm{Cr}$ are almost the same as those of Co. The values of indexes of the remaining metals are lower; thus, the sequence is $\mathrm{Co}=\mathrm{Cr}>\mathrm{As}>\mathrm{Pb}>\mathrm{Ni}>\mathrm{Cd}>\mathrm{Zn}>\mathrm{Cu}$.

The total hazard index $(H I)$ for the 3 years olds is $9.59 \mathrm{E}-02$ (residents) and $1.25 \mathrm{E}-02$ (visitors), while for the 6 years olds is $7.19 \mathrm{E}-02$ (residents) and $9.35 \mathrm{E}-03$ (visitors).

In the case of carcinogens, the highest risk has been calculated for As. The risk values of the 3 years olds are $1.27 \mathrm{E}-06$ and $1.65 \mathrm{E}-07$ (residents and visitors, respectively) while those of the 6 years olds $1.90 \mathrm{E}-06$ and $2.47 \mathrm{E}-07$ (residents and visitors, respectively). The risk values of the elements considered decrease for both age groups in the sequence As $>\mathrm{Cr}>\mathrm{Co}>\mathrm{Ni}>\mathrm{Cd}$.

With regard to the upper limits set for the two indexes, the total health risk $(H I)$ values in the case of all the elements considered are below a figure of 1 , while in the case of the cancerogenic substances are below a figure of $1.10 \mathrm{E}-05$.
Such results prove that the children playing in the sandboxes of the seven spas of Poland are not at endangered by the metals that the sandboxes contain.

\section{Discussion and conclusions}

Making a comparison of current data to those of other authors is difficult as the results depend mainly on different parameters accepted in calculating the HQ, such as the body mass, daily intake of soil (dirt) ingested and number of days or hours spent in playgrounds. Other reasons include sample types, sampling methods, contributions of the fractions separated to the total sample and extraction methods of metals from the solid sample. Therefore, the authors have decided to compare only the totals of metals in sandy materials or soils.

The sands of the sandboxes of Cracow, which is an agglomeration of almost a million of inhabitants located approximately up to $100 \mathrm{~km}$ south of the spas considered (except Swoszowice), i.e. immediately outside the Carpathians, were studied by Jasiewicz et al. (2009). The mean contents of $\mathrm{Cd}, \mathrm{Pb}$ and $\mathrm{Zn}$ of the spas (Table 6) are significantly lower: $0.06,2.05$ and $13.5 \mathrm{mg} /$ $\mathrm{kg}$, respectively, than those of Cracow: 0.08, 13.7 and $66.24 \mathrm{mg}$ / $\mathrm{kg}$, respectively. Comparable are the means of $\mathrm{Cu}: 1.27$ (range $0.56-2.24 \mathrm{mg} / \mathrm{kg}$ ) of the spas and 1.54 (range $0.65-4.95 \mathrm{mg} / \mathrm{kg}$ ) of Cracow. The means of $\mathrm{Cr}$ and $\mathrm{Ni}$ of the spas are around two times higher: 4.34 and $3.44 \mathrm{mg} / \mathrm{kg}$, respectively, than those of Cracow: 2.28 and $1.72 \mathrm{mg} / \mathrm{kg}$, respectively.

Considerable differences in the mean $\mathrm{Cd}, \mathrm{Pb}$ and $\mathrm{Zn}$ contents of sandbox sands occur between the spas (Table 6) and the region of Silesia (Kicińska 2016a, b; Nieć et al. 2013), the latter being the most industrialized region of Poland. They are even "several tens times lower than those of the Silesian playgrounds, where $\mathrm{Cd}$ ranges from 0.18 to $3.22, \mathrm{~Pb}$ from 31 to 115 and $\mathrm{Zn}$ from 57 to $522 \mathrm{mg} / \mathrm{kg}$ (the values refer to the towns Katowice and Sosnowiec, respectively). Comparable results were established by De Miguel et al. (2007) for Madrid: the mean contents of $\mathrm{As}, \mathrm{Cd}, \mathrm{Co}, \mathrm{Cr}, \mathrm{Ni}$ and $\mathrm{Zn}$ in Madrid were two to five times higher whereas of $\mathrm{Pb}$ and $\mathrm{Cu}$ around 9-10 lower than those in the spas of S Poland.

Considering soils of playgrounds, their significantly high contents of metals and similar distribution trends as in Cracow and Silesia (op. cit.) were noted in Owerri in Nigeria (Verla et al. 2015), Istanbul in Turkey (Namik et al. 2012) and Sao Paulo in Brazil (Figueiredo et al. 2011). However, these are all urban, not spa-status localities.

Although the $H I$ and risk indexes are below the values of a possible health threat for children, the authors recorded a significant pollution of the environment with metals, among which $\mathrm{As}$ and $\mathrm{Cr}$ are the major contributors. Both enter the human organism due to skin penetration and via the digestive tract (inadvertent swallowing of dirt); their entering via lungs when breathing is of minor importance. 


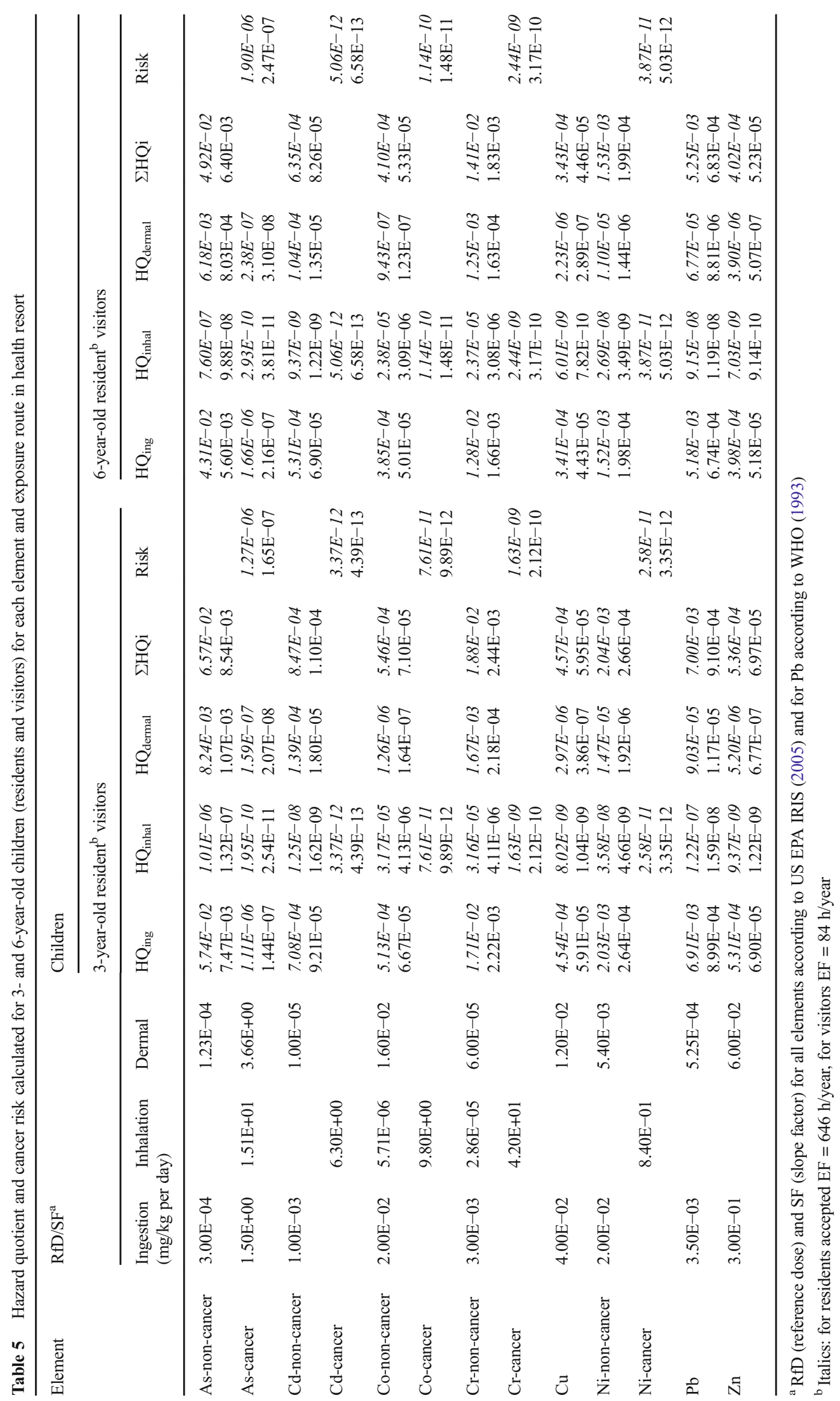




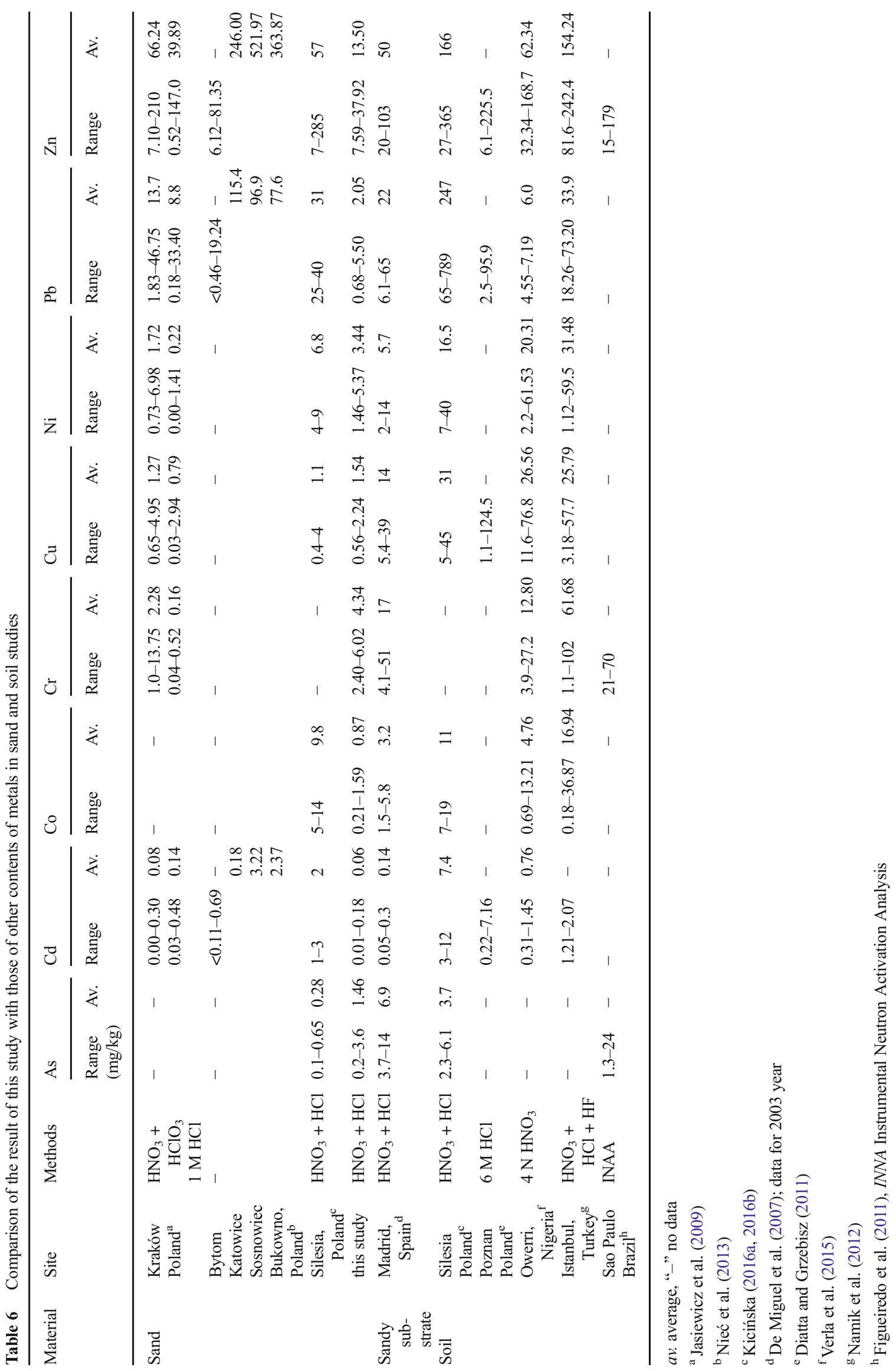


Compounds of arsenic show affinity to many enzymes. They accumulate in the bones, liver and kidneys and also in the tissues rich in keratin (Kabata-Pendias et al. 1993). A longlasting exposure to As and its excessive amounts in humans result in skin alterations and disorders in the functioning of the blood circulation, nervous and breathing systems. Arsenic is also a strong carcinogenic element (Zwozdziak et al. 2016).

Chromium occurs in the environment due to its chemical properties and relatively high resistance of $\mathrm{Cr}^{3+}$ compounds to weathering. Therefore, $\mathrm{Cr}^{3+}$ often accumulates in the hardly soluble residuum but, under oxidizing conditions, is adsorbed as $\mathrm{Cr}^{6+}$ by clay minerals and oxy/hydroxides of $\mathrm{Fe}$ and $\mathrm{Al}$ (Kicińska 2011). In the human organism, Cr may accumulate in the brain, spinal cord and kidneys. Together with As, chromium accumulates in children's hair and milk teeth, in which the two metals may be indicative of an overall metal pollution of the environment (Kicińska and Jelonek-Waliszewska 2017). Long-lasting exposure to $\mathrm{Cr}$ disturbs the circulatory and respiratory systems and results in skin diseases, while the chromic acid may seriously injure internal organs.

Chromium $\mathrm{Cr}^{6+}$ and ions of the remaining metals considered are bound to clay minerals as well as to Fe and Mn oxy/ hydroxides; these mineral phases form the finest grain fraction of the sands sampled in the current study. The grains of quartz that is chemically an inert mineral dominate in the samples. Therefore, the HQ index in the case of such quartz-rich materials as sands should be calculated on the basis of their finest fractions. A separate paper dealing with this issue is under preparation.

The problem of children exposure to arsenic in sandy substrate soils of Madrid playgrounds was dealt with by De Miguel et al. (2007), who determined 3.7-14 mg/kg As. The present authors have established in the sands of the Polish spas $0.2-3.6 \mathrm{mg} / \mathrm{kg}$ As and identified this element to be the largest single contributor to the overall health risk of children. The $H I$ indexes of $\mathrm{As}, \mathrm{Pb}, \mathrm{Cd}$ and $\mathrm{Cu}: 1.09 \mathrm{E}-01,3.11 \mathrm{E}-02,1.09 \mathrm{E}$ -03 and $1.41 \mathrm{E}-03$, respectively, calculated by De Miguel et al. (2007) for the children 6 years old in Madrid are considerably lower than those measured here in the Polish spas: $4.92 \mathrm{E}-02,5.25 \mathrm{E}-03,6.35 \mathrm{E}-04$ and $3.43 \mathrm{E}-04$, respectively. The $H I$ index of $\mathrm{Ni}$ in the sands of the Polish spas is slightly higher than that of Madrid (1.53E-03 and 9.6E-04, respectively), whereas the $\mathrm{HI}$ indexes of $\mathrm{Zn}$ and $\mathrm{Cr}$ are almost comparable $(7.10 \mathrm{E}-04$ versus $4.02 \mathrm{E}-04$, and $2.72 \mathrm{E}-02$ versus $1.41 \mathrm{E}-02$, respectively). The risk indexes calculated for cancerogens of the Polish spas are comparable only in the case of As to those of the Madrid parks, while significantly lower (at least by one order of magnitude) in the case of $\mathrm{Cd}, \mathrm{Ni}$ and $\mathrm{Cr}$ than the figures for Madrid.

Summarizing, the following conclusions can be drawn for the investigations of seven Polish spas:

1. The total values of the metals considered, i.e. As, $\mathrm{Cd}, \mathrm{Co}$, $\mathrm{Cr}, \mathrm{Cu}, \mathrm{Ni}, \mathrm{Pb}$ and $\mathrm{Zn}$, determined in the sands of the spa sandboxes are below the values permissible for the soils of the protected areas (type A).

2. The mobility of these metals is low and their fractions extracted with water contribute to the total metal contents between $0.7 \% \mathrm{TC}$ of $\mathrm{Pb}$ and $13 \% \mathrm{TC}$ of Cd.

3. The phytoavailable metal fractions extracted with EDTA and $\mathrm{CaCl}_{2}$ contribute in general considerably more to the total metal contents than do the waterleached fractions. The contribution of As is as high as $82 \% \mathrm{TC}$ on the average, however that of $\mathrm{Cr}$ only $0.7 \%$ TC (in EDTA-extraction). In the case of $\mathrm{CaCl}_{2}$ extraction, the values are much lower and range from slightly above $2 \% \mathrm{TC}$ of $\mathrm{Ni}$ to the highest $23 \% \mathrm{TC}$ of $\mathrm{Cd}$. The values obtained do not represent a significant threat to the soil-plant environment.

4. The total health risk indexes $H I$ calculated for noncancerogenic substances amount to $1.25 \mathrm{E}-02$ and $9.35 \mathrm{E}-03$ for the children 3 and 6 years old, respectively, who are permanent spa residents. For the children who are only spa visitors, the $H I$ indexes are much lower and amount to $9.58 \mathrm{E}-02$ and $7.19 \mathrm{E}-02$, respectively. The incidentally ingested arsenic is the major contributor to the indices, and its values for the children residing in spas are $5.74 \mathrm{E}-02$ for the 3 years olds and $4.31 \mathrm{E}-02$ for the 6 years olds. However, in the case of all the elements analysed, their $H I$ values are significantly below a level of 1 and prove the lack of hazardous impacts on children.

5. The highest risk values in the case of cancerogenic substances are those of As: $1.27 \mathrm{E}-06$ and $1.90 \mathrm{E}-06$ for 3and 6-year-old residents, respectively, and $1.65 \mathrm{E}-07$ and 2.47E-07 for 3- and 6-year-old visitors. Considerably lower values have been obtained for $\mathrm{Cr}>\mathrm{Co}>\mathrm{Ni}>\mathrm{Cd}$. As all these figures as below the permissible limit $(1.10 \mathrm{E}$ $-05)$, thus the risk factors of the metals considered are insignificant.

6. Despite a lack of the low health risk, an adverse overall impact of road traffic (the presence of such metals as $\mathrm{Cu}$, $\mathrm{Zn}, \mathrm{Ni}, \mathrm{Cr}, \mathrm{Co}$ and $\mathrm{Pb}$ ) and of low emissions (mainly As and $\mathrm{Cd}$ ) on the state of the environment in the spas has been established.

Acknowledgments This paper was supported by the AGH University of Science and Technology grant no. 11.11.140.017

Open Access This article is distributed under the terms of the Creative Commons Attribution 4.0 International License (http:// creativecommons.org/licenses/by/4.0/), which permits unrestricted use, distribution, and reproduction in any medium, provided you give appropriate credit to the original author(s) and the source, provide a link to the Creative Commons license, and indicate if changes were made. 


\section{References}

Alexander J (2006) Anbefalte kvalitetskriterier for jord i barnehager, lekeplasser og skolegårder på basert på helsevurderinger (Health-based soil quality criteria for day-care centres playgrounds and schoolyards). Oslo: Nasjonalt Folkehelseinstitutt [in Norwegian]

Boldo E, Medina S, LeTerte A, Hurley F, Mucke HG, Ballester F, Aguilera I, Elistein D (2006) Apheis: health impact assessment of long-term exposure to $\mathrm{PM}_{2.5}$ in 23 European cities. Eur J Epidemiol 21:449-458

De Miguel E, Iribarren I, Chacon E, Ordonez A, Charlesworth S (2007) Risk-based evaluation of the exposure of children to trace elements in playgrounds in Madrid (Spain). Chemosphere 66:505-513. doi: 10.1016/j.chemosphere.2006.05.065

Diatta JB, Grzebisz W (2011) Simulative evaluation of $\mathrm{Pb}, \mathrm{Cd}, \mathrm{Cu}$, and $\mathrm{Zn}$ transfer to humans: the case of recreational parks in Poznan. Poland Pol J Environ Stud 20(6):1433-1440

Dryglas D, Różycki P (2016) European spa resorts in the perception of non-commercial and commercial patients and tourists: the case study of Poland. e-Rev Tour Res (eRTR) 13(1/2):382-400

Du Y, Gao B, Zhou H, Ju X, Hao H, Yin S (2013) Health risk assessment of heavy metals in road dust in urban parks of Beijng, China. Procedia Environ Sci 18:299-309. doi:10.1016/j.proenv.2013.04.039

Ernst WHO (1996) Bioavailability of heavy metals and decontamination of soils by plants. Appl Geochem 11:163-167

Erway LC (1984) Genetic and developmental implications for trace metal metabolism from mutant and inbred strains of animals. In: Metabolism of Trace Metals in Man, 1:17-50

Ferreira-Baptista L, De Miguel E (2005) Geochemistry and risk assessment of street dust in Luanda, Angola: a tropical urban environment. Atmos Environ 39:4501-4512

Figueiredo AMG, Tocchini M, Santos TFS (2011) Metals in playground spoils of Sao Paulo city, Brazil. Procedia Environ Sci 4:303-309. doi:10.1016/j.proenv.2011.03.035

Guney M, Zgury GJ, Dogan N, Onay T (2010) Exposure assessment and risk characterization from trace elements following soil ingestion by children exposed to playgrounds, parks and picnic areas. J Hazard Mater 182:656-664. doi:10.1016/j. hazmat.2010.06.082

Houba VJG, Temminghoff EJM, Gaikhorst GA, van Vark W (2000) Soil analysis procedures using $0.01 \mathrm{M}$ calcium chloride as extraction reagent. Commun Soil Sci Plant Anal 31:9-10. doi:10.1080/ 00103620009370514

Jasiewicz C, Baran A, Antonkiewicz J (2009) Assessment of chemical composition and sanitary state of sand in selected sandboxes in Krakow. J Elem 14(1):79-90

Kabata-Pendias A, Pendias H (1999) Biogeochemistry of trace elements. PWN 279-288

Kabata-Pendias A, Mukherjee A (2007a) Trace elements from soil to human, Springer

Kabata-Pendias A, Piotrowska M, Witek T (1993) Assessment of soil and plants contamination by heavy metals and sulfur. Guidelines for Agriculture. Pulawy, IUNG, [in Polish]

Karczewska A, Gałka B, Kocan K (2009) A carryover effect of the chelating agents EDTA and EDDS applied to soils on the uptake of copper and iron by maize in the second year of a pot experiment. $\mathrm{J}$ Elem 14(4):693-703

Khaniabadi YO, Goudarzi G, Daryanoosh SM, Borgini A, Tittarelli A, De Marco A (2016) Exposure to PM10, NO2, and O3 and impacts on human health. Environ Sci Pollut Res. doi:10.1007/s11356-0168038-6

Kicińska A (2011) The chromium occurrence in soils and in plants from the Beskid Sąecki Mts. (Western Flysch Carpathian, Poland). Pol J Environ Stud 20(4A):125-129
Kicińska A (2016a) Health risk to children exposed to $\mathrm{Zn}, \mathrm{Pb}$ and $\mathrm{Fe}$ in selected urban parks of the Silesian agglomeration. Hum Ecol Risk Assess Int J 22(8):1687-1695. doi:10.1080/10807039.2016. 1218271

Kicińska A (2016b) Risk assessment of children's exposure to potentially harmful elements (PHE) in selected urban parks of the Silesian agglomeration. E3S Web of Conferences 10, 00035. doi:10.1051/ e3sconf $/ 20161000035$

Kicińska A, Bożęcki P (2017) Metals and mineral phases of dust collected in different urban parks of Krakow and their impact on the health of city residents. Environ Geochem Health. doi:10.1007/s10653017-9934-5

Kicińska A, Jelonek-Waliszewska A (2017) As and $\mathrm{Pb}$ and their potential source in the hair of residents of Cracow. J Elem. 22(2). doi:10.5601/ jelem.2016.21.3.1223

Lim JM, Jeong JH, Lee JH, Moon JH, Chung YS, Kim KH (2011) The analysis of $\mathrm{PM}_{2.5}$ and associated elements and their indoor/outdoor pollution status in an urban area. Indoor Air 21:145-155. doi:10. 1111/j.1600-0668.2010.00691

Ljung K, Oomen A, Duits M, Selinus O, Berglund M (2007) Bioaccessibility of metals in urban playground soils. J Environ Sci Health A Tox Hazard Subst Environ Eng 42(9):1241

Lo IMC, Yang XY (1999) EDTA extraction of heavy metals from different soil fractions and synthetic soils. Water Air Soil Pollut 109:219. doi:10.1023/A:1005000520321

Manouchehri N, Besancon S, Bermond A (2006) Major and trace metal extraction from soil by EDTA: equilibrium and kinetic studies. Anal Chim Acta 559(1):105-112. doi:10.1016/j.aca.2005.11.050

Mazzei F, Alessandro AD, Lucarelli F, Nava S, Prati S, Valli G, Vecchi R (2008) Characterization of particulate matter sources in an urban environment. Sci Total Environ 401:81-89. doi:10.1016/j. scitotenv.2008.03.008

Minister of Health (2005) Regulation of 28 July 2005 about health resorts, and protection areas and municipalities of spas, Dz.U. 2005.167.1399. [In Polish]

Minister of the Environment (2002) Soil quality standards and earth quality standards. Dz U 165:1359 [In Polish]

Ministerie van Volkshuisvesting (2000) Ruimtelijke Ordening en Milieubeheer, Dutch Target and Intervention Values. www.esdat. net/Environmental Standard/Dutch/annexS.12000

Namik A, Eroglu E, Guney I (2012) Statistical analysis of soil heavy metals of Istanbul children playgrounds. Energ Educ Sci Technol 28(2):1151-1158

Nieć J, Baranowska R, Dziubanek G, Rogala D (2013) Children's exposure to heavy metals in the soils of playgrounds, sports fields, sandpits and kindergarten grounds in the region of Upper Silesia. J Ecol Health 17(2):55-62

Pueyo M, Lopez-Sanchez J, Rauret G (2004) Assessment of $\mathrm{CaCl}_{2}$, $\mathrm{NaNO}_{3}$, and $\mathrm{NH}_{4} \mathrm{NO}_{3}$ extraction procedures for the study of $\mathrm{Cd}$, $\mathrm{Cu}, \mathrm{Pb}$ and $\mathrm{Zn}$ extractability in contaminated soils. Anal Chim Acta 504:217-226

Pysz K, Leszczyńska T, Bieżanowska-Kopeć R, Kopeć A (2016) Chemical assessment of lead, cadmium, nitrate, and nitrite intakes with daily diets of children and adolescents from orphanages in Krakow, Poland. Environ Sci Pollut Res 23:25200-25209. doi:10. 1007/s11356-016-7550-z

Rauret G (1998) Extraction procedures for the determination of heavy metals in contaminated soil and sediment. Talanta 46:449-455

Siudek P, Frankowski M, Siepak J (2015) Atmospheric particulate mercury at the urban and forest sites in central Poland. Environ Sci Pollut Res. doi:10.1007/s11356-015-5476-5

Siudek P, Kurzyca I, Siepak J (2016) Atmospheric deposition of mercury in central Poland: sources and seasonal trends. Atmos Res 170:14. doi:10.1016/j.atmosres.2015.11.0040169-8095

Smith M, Puczko L (2009) Health and wellness tourism. Elsevier, p 393 
Stajic JM, Milenkovic B, Pucarevic M, Stojic N, Vasiljevic I, Nikezic D (2016) Exposure of school children to polycyclic aromatic hydrocarbons, heavy metals and radionuclides in the urban soil of Kragujevac city, Central Serbia. Chemosphere 146:68-74. doi:10. 1016/j.chemosphere.2015.12.006

Szpunar J, Lobinska R, Prange A (2003) Hyphenated techniques for elemental speciation in biological system. Appl Spectrosc 57: $102 \mathrm{~A}-112 \mathrm{~A}$

Szyczewski P, Siepak J, Niedzielski P, Sobczyński T (2009) Research on heavy metals in Poland. Pol J Environ Stud 18(5):755-768

US EPA (1986) Guidelines for human health risk assessment of chemical mixtures. Federal Register (51 FR 34014-34025), Washington

US EPA (1996) Soil screening guidance: technical background document. EPA/540/R-95/128.Office of Solid Waste and Emergency Response. US Environmental Protection Agency. Washington. http://www.epa.gov/superfund/resources/soil/toc.htm\#p1

US EPA (1997) Exposure factors handbook - general factors. EPA/600/ P-95/002Fa, vol. I. Office of Research and Development. National Center for Environmental Assessment. US Environmental Protection Agency. Washington. http://www.epa.gov/ncea/pdfs/ efh/front.pdf

US EPA (2005) Integrated Risk Information System (IRIS). http://www. epa.gov/iris

US EPA (2011) Exposure Factors Handbook: 2011 Edition (EPA/600/R-09/ 052F). https://cfpub.epa.gov/ncea/risk/recordisplay.cfm?deid=236252
Verla EN, Ibutume SA, Horsfall M (2015) A preliminary survey of heavy metals concentrations in children playground within Owerri metropolis, Imo state, Nigeria. Res J Chem Sci 5(11):1-8

Wang J, Li S, Cui X, Li H, Qian X, Wang C, Sun Y (2016) Bioaccessibility, sources and health risk assessment of trace metals in urban park dust in Nanjing, southeast China. Ecotoxicol Environ Saf 128:161-170. doi:10.1016/j.ecoenv.2016.02.020

WHO (1993) Drinking-water quality. Guidelines for $3^{\text {rd }}$ ed. vol. 1 , Recommendations http://www.who.int/water sanitation_health

Yu L, Wang G, Zhang R, Zhang L, Song Y, Wu B, Li X, An K, Chu J (2013) Characterization and source apportionment of PM2.5 in an urban environment in Beijing. Aerosol Air Qual Res 13:574-582. doi:10.4209/aaqr2012.07.0192

Zhang N, Han B, He F, Xu J, Niu C, Zhou J, Kong S, Bai Z, Xu H (2015) Characterization, health risk of heavy metals, and source apportionment of atmospheric PM2.5 to children in summer and winter: an exposure panel study in Tianjin, China. Air Qual Atmos Health 8: 347-357. doi:10.1007/s11869-014-0289-0

Zwozdziak A, Sówka I, Willak-Janc E, Zwozdziak J, Kwiecińska K, Balińska-Miśkiewicz W (2016) Influence of $\mathrm{PM}_{1}$ and $\mathrm{PM}_{2.5}$ on lung function parameters in healthy schoolchildren-a panel study. Environ Sci Pollut Res 23:23892-23901. doi:10.1007/s11356-016$7605-1$ 